\title{
PATENTLY NON-ObVIOUS II: EXPERIMENTAL STUdY ON THE HINDSIGHT ISSUE BEFORE THE SUPREME COURT IN KSR V. TELEFLEX
}

\author{
GREGORY MANDEL*
}

\begin{abstract}
For the first time in thirty years, the Supreme Court will consider the core patent requirement that an invention be non-obvious. At the heart of the case lies the challenge of how to insulate non-obvious decisions from the distortion of the hindsight bias. This Article reports the latest empirical studies in a line of hindsight research, which present experimental data bearing directly on the issue before the Court: how individuals make non-obvious decisions under existing Supreme Court and Federal Circuit precedent.

The study results indicate that the Federal Circuit's suggestion, teaching, or motivation requirement, the precedent challenged before the Supreme Court in KSR v. Teleflex, does not produce erroneous nonobvious outcomes. This result contradicts the claims of the petitioners in KSR and other critics of the suggestion requirement. On the other hand, the results do not demonstrate that the suggestion test ameliorates the hindsight bias in the manner usually claimed by its supporters. An additional study indicates that the Supreme Court's Graham framework does not resolve the hindsight problem either. Given the substantial and confirmed prejudicial effect of the hindsight bias, the Article concludes that the suggestion test should be retained for several reasons: it does not appear to cause the harms hypothesized by its critics, it potentially reduces the hindsight bias for complex technology inventions, and the problem the test confronts (erroneous decisions that an invention is obvious in hindsight) is known and significant while the problem the test is alleged to create (over-compensation for the hindsight bias) is unconfirmed and conjectural.

The Article concludes with a recommendation for bifurcating the nonobvious decision at the Patent and Trademark Office. Combined with an earlier proposal for jury trials, these recommendations present the only known means for eliminating the hindsight effect and producing patent decisions that comport with the Patent Act and Supreme Court precedent.
\end{abstract}

\footnotetext{
* (C) 2006 Gregory N. Mandel. Associate Dean for Research \& Scholarship and Professor of Law, Albany Law School. I am grateful to the participants of the Intellectual Property Scholars Conference at Boalt Hall-Berkeley Law School, the Conference on Empirical Legal Studies at the University of Texas School of Law, Patent Law: Recent Development and Proposals for Reform at Santa Clara School of Law, and the Intellectual Property Colloquium at the University of Arizona College of Law for their helpful comments.
} 


\section{TABLE OF CONTENTS}

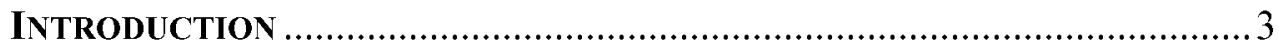

I. The Non-ObVIOUS Hindsight BIAS................................................ 6

II. SUgGestion TeSt AND GraHaM Framework EXPERIMENTAL

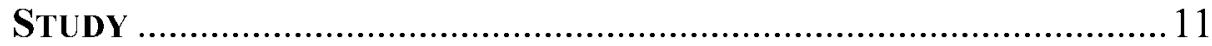

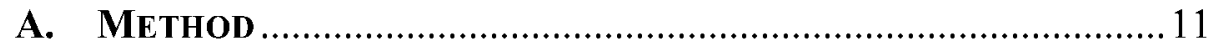

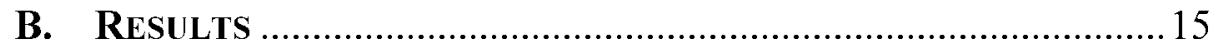

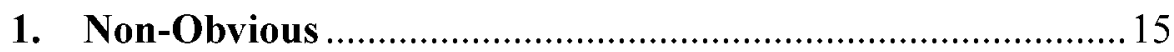

2. Federal Circuit Suggestion Instructions ................................16

3. Supreme Court Graham Instructions.......................................17

4. Confidence in Non-Obvious Judgment …………………........ 17

5. Likelihood of Invention ........................................................ 17

C. DisCUSSION .......................................................................... 18

III. FROM EXPERIMENTAL STUDY TO REAL WORLD IMPLICATIONS........20

IV. CONSEQUENCES OF THE STUDY FOR THE SUPREME COURT IN KSR $\boldsymbol{V}$.

TELEFLEX

A. The Federal Circuit's Suggestion Test .............................27

B. IMPLICATIONS OF THE STUDY FOR THE SUGGESTION

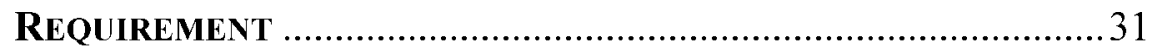

C. AChiEving ACCurate Non-ObVious Decisions.........................34

CONCLUSION .....................................................................................

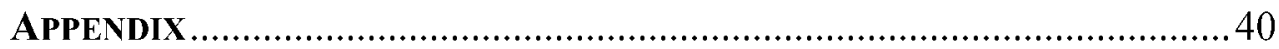




\section{INTRODUCTION}

Patent law faces a critical quandary. The core requirement for obtaining a patent is that the invention was not obvious at the time it was invented. Only significant technological advances merit award of a patent. Determining whether an invention was non-obvious in the past, however, raises the daunting specter of hindsight. Once we know that the invention was achieved-and even more prejudicially, how it was achieved-the invention inevitably appears to have been more obvious than it actually was. The Supreme Court is currently considering this problem in KSR $v$. Teleflex. ${ }^{1}$

The hindsight effect is familiar to all-consider the widespread adages "hindsight is 20/20" or "Monday morning quarterback." These sayings are based on a now well-proven fact: once outcome information is known, people are cognitively incapable of preventing that information from influencing their understanding of past events. As a result, individuals consistently (and unconsciously) exaggerate what could have been anticipated in foresight and not only tend to view what occurred as having been inevitable, but also as having appeared relatively inevitable beforehand.

This hindsight effect creates substantial difficulty for patent law. Judges, jurors, and patent examiners will routinely view inventions that were actually non-obvious at the time of invention as instead having been obvious, because the invention is known to the decision-maker at the time the non-obvious determination is made in hindsight. The first study in the current line of research confirmed this effect. That study of mock jurors charged with evaluating whether a patented invention was obvious concluded, "the hindsight bias significantly influences non-obvious judgments . . . . Ex post knowledge of invention deeply affect[s] participants' conclusions regarding whether an invention [is] non-obvious ex ante." 2 The study also found that the magnitude of hindsight bias for non-obvious decisions was greater than that reported for other legal judgments. ${ }^{3}$

The judiciary and others engaged in patent law and patenting have been aware of the potential hindsight problem for some time. In its seminal non-obvious decision forty years ago, the Supreme Court expressed concern about the hindsight problem and implemented case law to try to mitigate it. ${ }^{4}$ Similarly, the Federal Circuit (the Federal Court of Appeals for most patent

\footnotetext{
${ }^{1}$ KSR Int'l Co. v. Teleflex, Inc., 2006 WL 3257150 (U.S.), cert. granted, 75 USLW 3262 (U.S. June 26, 2006) (No. 04-1350).

2 Gregory Mandel, Patently Non-Obvious: Empirical Demonstration that the Hindsight Bias Renders Patent Decisions Irrational, 67 OHIO ST. L.J. (forthcoming 2006), available at http://papers.ssrn.com/sol3/papers.cfm?abstract_id=871684, at 16.

${ }^{3} \mathrm{Id}$.

${ }^{4}$ Graham v. John Deere Co., 383 U.S. 1, 36 (1966).
} 
appeals) has strived for years to reduce or eliminate the impact of hindsight on patent decisions. The primary jurisprudence the Federal Circuit has developed to combat the bias is the "suggestion test"-a requirement that there be some pre-existing suggestion, teaching, or motivation to combine references in order to combine such references in the non-obvious analysis. ${ }^{5}$ A challenge to the validity of the suggestion test is the sole issue before the Supreme Court in KSR v. Teleflex. ${ }^{6}$

The petitioner in KSR, backed by amici briefs from the Solicitor General of the United States, ${ }^{7}$ industry representatives, ${ }^{8}$ and a number of intellectual property professors, ${ }^{9}$ argues that the suggestion test violates the Patent Act and the Supreme Court's non-obvious precedent because it results in certain actually obvious advances instead being held non-obvious. Their argument is that combining references may have been obvious even if there was no explicit suggestion, teaching, or motivation to combine the references in the prior art.

The experimental study reported here indicates that these contentions are not supported by the reality of human decision-making. Mock jurors who received a jury instruction to apply the suggestion requirement were no more likely to conclude that an invention was nonobvious than mock jurors who received no suggestion instruction. The suggestion test does not appear to have the problematic effect asserted by its detractors.

Though the study reveals that concerns about the suggestion test are unconfirmed, supporters of the test should not rejoice too hastily. The results also indicate that the suggestion requirement does not mitigate the hindsight bias in the manner assumed by the Federal Circuit. Mock jurors who received the suggestion instructions were no less prone to the hindsight bias than those who received no instruction.

Consequently, the study reveals that the debate before the Supreme Court over the suggestion test is foundationally misplaced. The debate, as currently constituted, focuses on whether the suggestion test is overbroadwhether, in an effort to reduce the hindsight bias, the test also precludes decision-makers from considering all appropriate evidence of obviousness.

${ }^{5}$ In re Dembiczak, 175 F.3d 994 (Fed. Cir. 1999); In re Rouffet, 149 F.3d 1350 (Fed. Cir. 1998).

62006 WL 3257150.

${ }^{7}$ Brief for the United States as Amici Curiae in Support of Petitioner, KSR Int'l Co. v. Teleflex, Inc., 75 USLW 3262 (U.S. June 26, 2006) (No. 04-1350) [hereinafter Brief of the United States].

${ }^{8}$ Brief of Cisco Systems Inc., Microsoft Corp., Hallmark Cards Inc., V.F. Corp., and Fortune Brands Inc. as Amici Curiae in Support of Petitioner, KSR Int'l Co. v. Teleflex, Inc., 2005 WL 1503650 (U.S. June 22, 2005) (No. 04-1350) [hereafter Industry Amici Brief].

${ }^{9}$ Brief of Twenty-Four Intellectual Property Law Professors as Amici Curiae in Support of Petitioner, KSR Int'l Co. v. Teleflex, Inc., 2005 WL 1334163 (U.S. May 12, 2005) (No. 04-1350) [hereinafter IP Professors' Amici Brief ]. 
Both supporters and detractors of the suggestion test appear to take as a given that the suggestion requirement does ameliorate the hindsight bias; supporters argue that it does so appropriately, while detractors effectively argue that it goes too far. The findings reported here reveal that these base assumptions are false. The Federal Circuit's suggestion, teaching, or motivation requirement actually does not resolve the hindsight bias in the first instance.

The instant study also examines the impact of Supreme Court jurisprudence on the hindsight bias in non-obvious decisions. Under the Supreme Court's decision in Graham, a judge or jury must follow a carefully structured framework in order to determine whether an invention is non-obvious. The study indicates that, like the suggestion requirement, the Graham framework does not ameliorate the hindsight bias. Mock jurors who were instructed to follow the Graham framework in a manner based on model patent jury instructions demonstrated no less hindsight effect than mock jurors who were not so instructed.

The hindsight bias thus remains unresolved in patent law. It is appropriate, therefore, to repeat a call to bifurcate the non-obvious issue whenever possible - this remains the only means identified to eliminate the hindsight bias in patent decisions. A proposal for bifurcating jury trials is discussed in detail in my earlier work on the hindsight bias. ${ }^{10}$ The present article introduces a new technique to bifurcate the non-obvious issue in patent examination at the Patent and Trademark Office (PTO). Bifurcation is the only means identified to achieve non-obvious decisions that comport with the non-obvious requirement enacted in the Patent Act and developed in Supreme Court precedent.

For circumstances in which the non-obvious issue cannot be bifurcated (most significantly, cases tried to judges), the suggestion, teaching, or motivation test remains a legitimate second-best option. The results reported here indicate that the suggestion test does not distort nonobvious decisions in the manner claimed by critics. In addition, as discussed below, the test may help mitigate the hindsight bias for certain types of invention that would not have been identified in these studies (for example, complex technology inventions). As the hindsight bias is known to substantially prejudice non-obvious decisions, the suggestion test should be retained because the problem it confronts (erroneous decisions that an invention is obvious in hindsight) is known and significant, while the problem the test is alleged to create (over-compensation for the hindsight bias) is unconfirmed and conjectural. In addition, the suggestion test provides a valuable analytical framework for decision-makers otherwise faced with a relatively unguided decision concerning whether it was obvious to combine references.

${ }^{10}$ Mandel, supra note 2, at 45-47. 
Part I of this article introduces patent law's non-obvious requirement and the hindsight problem. The experimental studies that investigate Supreme Court and Federal Circuit non-obvious jurisprudence are reported in Part II. Part III explains why the results reported in this study are expected to represent real world non-obvious decisions by judges, jurors, and patent examiners. Part IV of the article analyzes the impact of this study for existing non-obvious jurisprudence and for the Supreme Court in $K S R$ v. Teleflex, and introduces a proposal to bifurcate the non-obvious decision at the PTO.

\section{The Non-Obvious Hindsight Bias}

An inventor must satisfy several validity requirements in order to obtain a patent, ${ }^{11}$ but one requirement stands out as paramount: the nonobvious requirement. ${ }^{12}$ It is the non-obvious requirement that commonly presents the greatest hurdle to an inventor and it is this requirement that protects society against the social costs both of denying a deserving patent and of granting an undeserving monopoly. ${ }^{13}$ Improper application of the non-obvious standard would either result in inefficiently low incentives to innovate (reducing technological innovation) or allow the patenting of trivial advances, leading to inefficient patent thickets, and similarly reducing future technological advance. ${ }^{14}$ In addition, proper application of the non-obvious standard is necessary to comply with the constitutional requirement that patents promote progress. ${ }^{15}$ The non-obvious requirement thus stands at the center of innovation policy and the technology economy in the United States. The importance of the non-obvious requirement is demonstrated by the reality of patent litigation-the non-obvious requirement is both the most commonly litigated patent validity issue and

11 The patent validity requirements are: subject matter, utility, novelty, non-obvious, and adequate disclosure. 35 U.S.C. $\$ \S 101-03,112$ (2000).

1235 U.S.C. $\$ 103$ (2000); NONOBVIOUSNESS-THE ULTIMATE CONDITION OF Patentability (J. Witherspoon ed. 1980); Hon. Giles S. Rich, Laying the Ghost of the "Invention" Requirement, 1 APLA Q. J. 26 (1972).

13 Bonito Boats, Inc. v. Thunder Craft Boats, Inc., 489 U.S. 141, 151, 156 (1989) (The non-obvious standard provides "a careful balance between the need to promote innovation and the recognition that imitation and refinement through imitation are both necessary to invention itself and the very lifeblood of a competitive economy."); Graham v. John Deere Co., 383 U.S. 1, 6 (1966) ("Innovation, advancement, and things which add to the sum of useful knowledge are inherent requisites in a patent system which by constitutional command must promote the Progress of . . . useful Arts. This is the standard expressed in the Constitution and it may not be ignored." (internal quotations omitted)).

14 Fed. Trade Comm'n, To Promote innovation: The Proper Balance of COMPETITION AND PATENT LAW AND POLICY, ch. 4, at 6-7 (2003); Dan L. Burk \& Mark A. Lemley, Policy Levers in Patent Law, 89 VA. L. REV. 1575, 1577, 1586 (2003); RoBERT MERGES \& JOHN DUFFY, PATENT LAW AND POLICY: CASES AND MATERIALS 646-47 (3d ed. 2002).

15 Graham, 383 U.S. at 6; Rich, supra note 12, at 26. 


\section{Non-Obvious: EXPERIMENTAL Study ON THE Hindsight IsSUE}

the patent validity requirement most likely to result in a patent being held invalid. 16

The Patent Act's non-obvious requirement provides that a patent shall not issue for an invention if

the differences between the subject matter sought to be patented and the prior art are such that the subject matter as a whole would have been obvious at the time the invention was made to a person having ordinary skill in the art to which said subject matter pertains. ${ }^{17}$

Though the non-obvious requirement sounds logical, in practice humans are cognitively incapable of applying it accurately in the manner currently required. Proper non-obvious determinations are unattainable under existing jurisprudence because they require the use of hindsight. The decision should turn on whether the invention was non-obvious in the ex

16 John R. Allison \& Mark A. Lemley, Empirical Evidence on the Validity of Litigated Patents, 26 AIPLA Q. J. 185, 208-09 (1998); see also GLORIA K. KOENIG, PATENT InVAlidity: A STATISTICAL AND SUbSTANTIVE ANALYSIS 5-50 (rev. ed. 1980) (finding that obviousness was the most common basis for judicial invalidation of patents for the period 1953-1978); P.J. Federico, Adjudicated Patents, 1948-54, 38 J. PAT. OfF. SoC'Y 233, 249 (1956) (finding that obviousness was the most common basis for judicial invalidation of patents for the period studied). Obviousness was litigated in 160 out of 300 patent validity decisions issued in the almost eight-year period of Allison and Lemley's study; the second most common issue ( $\S 102$ prior art) was litigated in only about half as many decisions. Allison \& Lemley, supra, at 209. Obviousness was a basis in nearly half $(42 \%)$ of all cases in which a patent was held invalid. $I d$. at 208.

1735 U.S.C. $\$ 103($ a). The non-obvious requirement was formally introduced in the 1952 Patent Act. 35 U.S.C. $\$ 103$. Prior to 1952, courts recognized that something more than novelty was required for patentability and had read a requirement similar to nonobviousness into the term "invention" in the Patent Act. Graham, 383 U.S. at 15-17. For instance, one hundred years before the non-obvious requirement was formally added in the Patent Act, the Supreme Court in Hotchkiss v. Greenwood held that, "unless more ingenuity and skill ... were required in [making the claimed invention] ... than were possessed by an ordinary mechanic acquainted with the business, there was an absence of that degree of skill and ingenuity which constitute essential elements of every invention. In other words, the improvement is the work of the skillful mechanic, and not that of the inventor." 52 U.S. (11 How.) 248, 267 (1850).

Two patent reform bills are currently pending in Congress. Patent Reform Act of 2006, S. 3818, 109th Cong. (2d Sess. 2006); Patent Reform Act of 2005, H.R. 2795, 109th Cong. (1st Sess. 2005). Neither bill would significantly affect the issues discussed here. As proposed, each bill would revise the non-obvious standard in $\S 103$ (a) to evaluate obviousness at the time of filing as opposed to the time of invention. Patent Reform Act of $2006 \S 3(\mathrm{c})$; Patent Reform Act of $2005 \S 3(\mathrm{c})$. Most non-obvious determinations already are effectively based on this time because the filing date is currently treated as the constructive invention date, and an earlier actual invention date usually is not established. Oka v. Youssefyeh, 849 F.2d 581 (1988). In addition, it is knowledge of the invention that produces the hindsight effect, not the length of time since the historic date used for the nonobvious evaluation. 
ante world just prior to the invention's creation, when the invention and how to achieve it were still unknown. A proper non-obvious decision must not take into account the ex post fact that the invention actually was achieved. Unfortunately, this mandate is far easier stated than accomplished. Humans are cognitively unable to prevent knowledge gained through hindsight (here, that the invention was achieved) from impacting their analysis of past events, as required for the proper ex ante analysis. ${ }^{18}$ Because of this hindsight bias, individuals routinely overestimate the ex ante predictability of events after they have occurred. ${ }^{19}$ Critical for patent law, once individuals have hindsight information, they consistently exaggerate what could have been anticipated in foresight and not only tend to view what has occurred as having been inevitable, but also as having appeared "relatively inevitable" beforehand. ${ }^{20}$

The human incapacity to ignore hindsight information has been well-studied and documented in a variety of contexts. The hindsight bias has been confirmed in over one-hundred studies of both lay and expert judgment in both laboratory and real world settings in many fields. ${ }^{21}$ The hindsight bias has been verified in legal decision as well. Several mock jury studies in the tort and search and seizure contexts have demonstrated significant hindsight effects in judging negligence and probable cause, respectively. ${ }^{22}$

The first study in the current line of patent hindsight bias research revealed that patent law is not immune from this concern. That study

18 Baruch Fischhoff, For Those Condemned to Study the Past: Heuristics and Biases in Hindsight, in JUDGMENT UNDER UNCERTAINTY: HEURISTICS AND BIASES 335 (Kahneman et al. eds., 1982).

${ }^{19} \mathrm{Id}$. at 341.

${ }^{20} \mathrm{Id}$.

21 J. J. Christensen-Szalanski \& C. F. Willham, The Hindsight Bias: A Meta-analysis, 48 Organizational Behav. \& Hum. Decision Processes 147 (1991) (meta-analysis of 128 hindsight bias studies, 122 of which reported a hindsight bias); Kim A. Kamin \& Jeffrey J. Rachlinski, Ex Post $\neq$ Ex Ante: Determining Liability in Hindsight, 19 LAw \& HuM. BEHAV. 89, 90-91 (1995) (citing studies revealing hindsight bias in surgeons' appraisal of surgical cases, physicians' medical diagnoses, women's' reactions to pregnancy tests, voters' election predictions, and nurses' employee evaluations); see also Susan J. LaBine \& Gary LaBine, Determinations of Negligence and the Hindsight Bias, 20 LAW \& HuM. BEHAV. 501, 502-04 (1996) (surveying a wide variety of hindsight bias studies).

22 Kamin \& Rachlinski, supra note 21, at 98-99; LaBine \& LaBine, supra note 21; CASS R. Sunstein et Al., Punitive Damages: How Juries DeCide 103-04 (2002); D.K. Kagehiro et al., Hindsight Bias and Third-Party Consents to Warrentless Police Searches, $15 \mathrm{LAW} \&$ Hum. Behav. 305 (1991); J.D. Casper et al., Juror Decision Making, Attitudes, and the Hindsight Bias, 13 LAW \& Hum. BEHAV. 291 (1989); J.D. Casper et al., Cognition, Attitudes and Decision-Making in Search and Seizure Cases, 18 J. OF APPLIED SOC. PSYCHOL. 93 (1988). Another study found a hindsight effect in criminal cases where jurors were instructed to disregard information about a prior trial outcome. Galen V. Bodenhausen, Second-Guessing the Jury: Stereotypic and Hindsight Biases in Perceptions of Court Cases, 20 J. APPLIED SOC. PSYCHOL. 1112 (1990). 


\section{Non-Obvious: EXPERIMENTAL STUdy ON THE Hindsight IsSuE}

demonstrated a significant hindsight effect in non-obvious decisions. ${ }^{23}$ The magnitude of the hindsight effect was as great as or greater than that found in other legal judgment studies. ${ }^{24}$

Although the effect of the hindsight bias in patent law was more severe and pervasive than expected, its existence was not surprising. Courts and commentators had suspected a hindsight problem in patent law for some time. Over a century ago the Supreme Court identified a concern about judging combination inventions in hindsight: "Now that [the invention] has succeeded, it may seem very plain to any one that he could have done it as well."25 Similarly, in Graham, the seminal Supreme Court decision concerning the non-obvious requirement of the Patent Act, the Court explicitly warned against "slipping into use of hindsight" in nonobvious determinations. ${ }^{26}$ The Federal Circuit has likewise recognized that solving the hindsight problem is critical to proper non-obvious decisions. ${ }^{27}$

The Supreme Court and Federal Circuit have developed several jurisprudential tools in an effort to combat the hindsight problem: the Federal Circuit's requirement of a suggestion, teaching, or motivation to combine prior art in the non-obvious analysis; 28 the use of secondary consideration evidence; ${ }^{29}$ and jury instruction warning jurors about the hindsight bias and instructing them to avoid it. ${ }^{30}$ The earlier hindsight study

23 Mandel, supra note 2, at 14-15.

$24 I d$. at 16 (comparing the study reported, in which an average of $39 \%$ of mock jurors shifted their decisions concerning non-obviousness in two patent scenarios, with hindsight studies concerning negligence ( $28 \%$ and $34 \%$ of jurors shifted decisions in two studies), punitive damages ( $24 \%$ of mock jurors shifted decision), and civil rights litigation ( $24 \%$ of jurors shifted decision)).

25 Loom Co. v. Higgins, 105 U.S. 580, 591 (1882).

26 Graham v. John Deere Co., 383 U.S. 1, 36 (1966) (citing Monroe Auto Equipment Co. v. Heckethorn Mfg. \& Sup. Co., 332 F.2d 406, 412 (1964)).

27 See, e.g., In re Dembiczak, 175 F.3d 994 (Fed. Cir. 1999); In re Rouffet, 149 F.3d 1350 (Fed. Cir. 1998).

28 In re Dembiczak, 175 F.3d 994; In re Rouffet, 149 F.3d 1350.

29 Graham, 383 U.S. at 36; Stratoflex, Inc. v. Aeroquip, 713 F.2d 1530, 1539 (Fed. Cir. 1983).

30 See FEDERAL CIRCUIT BAR ASSOCIATION, MODEL PATENT JURy InstruCtions, http://www.fedcirbar.org/documents/forms/LINKS/-

$\% 20 F E D . \% 20$ CIR.\%20FINAL\%20VERSION\%20(3) .PDF [hereinafter FEDERAL CIRCUIT BAR ASSOCIATION, MODEl PATENT JuRy Instructions]; American Intellectual Property Law Association, MODEL JURY INSTRUCTIONS, http://www.aipla.org/Content/ContentGroups/Publications1/Guide_to_Model_Patent_Jury_ Instructions.htm [hereinafter AIPLA MODEL PATENT JURY INSTRUCTIONS"). The presumption of validity that adheres to issued patents, see 35 U.S.C. $\$ 282(2000)$, is sometimes (inappropriately) identified as a potential remedy to the hindsight problem. The presumption of validity, however, is not intended to address the hindsight problem. 35 U.S.C. $\$ 282$. The presumption also lacks utility to address the hindsight problem: the presumption's effect is unknown in extent, it does not apply to patent examiners, and at best would result in the wrong patents surviving non-obvious challenges not in the correct patents being held valid. Mandel, supra note 2, at 36-37. 
evaluated the latter two solutions, and revealed that neither successfully mitigated the bias. In a "debiasing" condition in the earlier study, mock jurors were explicitly warned about the hindsight bias and instructed to guard against it in a manner based on Model Jury Instructions. The warned jurors did not display a statistically lower hindsight bias than jurors who received no warning. ${ }^{31}$ The prior study also evaluated eighteen months of Federal Circuit and District Court non-obvious decisions to evaluate the use of secondary consideration evidence. The empirical analysis concluded that, based on how infrequently secondary consideration evidence is both available and reliable, secondary consideration evidence "appears to affect only a couple percent of non-obvious decisions," an impact far too low to mitigate the hindsight bias. 32

The present study evaluates the Federal Circuit's suggestion, teaching, or motivation requirement, the only remaining tool in existing patent law proffered to combat the hindsight bias in non-obvious decisions. The rationale behind the suggestion requirement is relatively straightforward. Due to the hindsight bias, decision-makers will be excessively prone to believe that it was obvious to combine various elements in the prior art in order to achieve the invention. ${ }^{33}$ As a result, nearly every invention will appear obvious as the decision-maker picks and chooses the various necessary elements of an invention from the available prior art. ${ }^{34}$ In an attempt to mitigate this erroneous tendency, Federal Circuit caselaw requires a "suggestion, teaching, or motivation" to combine the references in the prior art in order to combine the references as part of the non-obvious analysis. ${ }^{35}$ The suggestion test is implemented in an effort to provide a more objective check on whether it actually was obvious to combine certain references, or whether it only appears obvious to combine the references in hindsight. This rule was established directly in an effort to avoid hindsight bias: "the best defense against the subtle but powerful attraction of a hindsight-based obviousness analysis is the rigorous application of the requirement for a showing of the teaching or motivation to combine prior art references." 36

The validity of the suggestion test is the issue before the Supreme Court in KSR v. Teleflex. The petitioners, the Solicitor General, and allied amici contend that rigorous application of the suggestion test violates the Patent Act and the Supreme Court's non-obvious precedent because combining references may be obvious even in situations where there is no suggestion, teaching, or motivation to do so.

${ }^{31}$ Mandel, supra note 2, at 15.

$32 \mathrm{Id}$. at $24-27$.

33 In re Dembiczak, 175 F.3d 994; In re Rouffet, 149 F.3d 1350.

34 Ruiz v. A.B. Chance Co., 357 F.3d 1270 (Fed. Cir. 2004); Interconnect Planning Corp.

v. Feil, 774 F.2d 1132 (Fed. Cir. 1985).

35 In re Rouffet, 149 F.3d at 1357; In re Dembiczak, 175 F.3d at 999.

${ }^{36}$ In re Dembiczak, 175 F.3d at 999. 
In addition to testing the Federal Circuit's suggestion test, this study also examined the impact of the Supreme Court's Graham framework on the hindsight bias. The Supreme Court did not propose the Graham framework as a solution to the hindsight problem per se, but the Court was acutely aware of the hindsight problem when it drafted its decision in Graham. ${ }^{37}$ In addition, several challengers of the suggestion test content that the test can be eliminated because the Graham framework adequately ameliorates the hindsight bias. ${ }^{38}$ Any attempt to resolve the hindsight bias for non-obvious determinations requires an understanding of the impact of Graham on the bias.

\section{SUgGESTION TEST AND GRAHAM FraMeWORK EXPERIMENTAL STUDY}

Despite the heated debate surrounding the suggestion, teaching, or motivation doctrine, no one has previously tested the actual impact of the suggestion requirement on non-obvious decisions. This section presents the empirical results of original experimental research conducted to evaluate the effect of suggestion test, and Graham, jurisprudence on the hindsight bias in non-obvious determinations.

The study addresses the following primary hypotheses: (1) requiring a suggestion, teaching, or motivation to combine references in a nonobvious determination will not ameliorate the hindsight bias, and will not prejudice the decision-maker towards a conclusion that the invention is nonobvious, and (2) application of the Graham framework to a non-obvious analysis will not mitigate the hindsight effect. The study, like the first one in this line of research, also included questions to address the following related hypotheses: (3) hindsight knowledge will not influence an individual's confidence in his or her judgment of whether an invention is obvious, and (4) hindsight information will increase an individual's judgment of the ex ante likelihood of an invention being achieved.

\section{A. Method}

Participant mock jurors were given a hypothetical fact scenario concerning an invention. ${ }^{39}$ The participants were jury-eligible citizens approached in public places and asked to take part in a survey study in exchange for a lottery ticket. Participants were approached in a variety of places where it was likely to find individuals who were already sitting down and who might have time available for the study. Recruitment locations

\footnotetext{
37383 U.S. 1, 36 (1966).

38 Brief of the United States, supra note 7, at 10, 16, 21; IP Professors' Amici Brief, supra note 9, at 9; Industry Amici Brief, supra note 8, at 3.

39 The scenario is described below and included in the Appendix.
} 
included various eating and coffee establishments, shopping malls, airports, and public parks.

In order to establish juror-eligibility, the survey included questions concerning the participant's citizenship, age, and felony conviction status. ${ }^{40}$ Eight participants answered one of the eligibility questions in a manner that would preclude them from actual jury service and were excluded from the study results (each still received a lottery ticket). ${ }^{41} 384$ eligible participants took part in the study.

The scenario was based on facts surrounding an actual issued patent that was challenged on non-obvious validity grounds in litigation and was the subject of a reported decision. ${ }^{42}$ The scenario included background information about the field of art of the invention, a variety of prior art reference information, a description of the problem that a person cast in the role of the inventor was working on, and a questionnaire. The scenario was selected for an invention that would be easy for mock jurors to comprehend (to reduce the need for significant material on the skill level of a person having ordinary skill in the art ("PHOSITA")), ${ }^{43}$ and for an invention that presented an apparently disputable question of non-obviousness. ${ }^{44}$ The inventions, prior art, and facts were modified in part from the actual case in order to meet these and other practical concerns. The scenario used here was the same as one of the two used in an earlier patent hindsight bias study; ${ }^{45}$ of the two used in the prior study, this one was selected based on the ease of understanding the field of art.

40 See 28 U.S.C. $\$ 1865$ (2000) (federal juror eligibility requirements). The consent form, handed to potential participants prior to their being given a survey, similarly informed potential participants that they would not be eligible for the study unless they were a United States citizen, at least 18 years of age, and had not been convicted of a felony.

41 In addition to establishing the likelihood of juror-eligibility, the responses to the eligibility questions also indicate that the participants paid close attention to the questions. Of the eight ineligible respondents, four answered that they were not a citizen, and four answered that they had been convicted of a felony. The citizen question required a "yes" answer for eligibility, the felony question a "no." Although one cannot tell whether the participants who answered each of these questions in a manner that rendered them ineligible answered in error, these results indicate a maximum error rate of $1 \%$ in participant responses, and thus that participants paid careful attention to these questions and answers.

42 The scenario was based on the facts reported in McGinley v. Franklin Sports, Inc., 262 F.3d 1339 (Fed. Cir. 2001).

43 In this manner, this study imitated the Supreme Court's decision in Graham, where the Court first instituted the PHOSITA analysis, and implicitly applied its own (lay) understanding of what a person having ordinary skill in the art would know. See Graham, 383 U.S. at 24-26, 32-35 (conducting an analysis of whether the inventions at issue were obvious to a PHOSITA without any factual record concerning what a PHOSITA would know or know how to do).

44 This latter condition was sought by selecting a case in which the court's non-obvious analysis indicated that the result was not entirely clear.

45 Mandel, supra note 2, at 12-14. 


\section{NON-ObVIOUS: EXPERIMENTAL STUDY ON THE HindSIGHT ISSUE}

The scenario concerned baseball instruction; particularly, instructional materials for teaching people how to throw different types of baseball pitches (for example, a fastball, curveball, or sinker). The prior art described in the scenario included instructional videos showing how to hold and release different pitches, articles and books which described how to hold and release different pitches, cards which showed a picture of a hand holding a baseball in the proper way to make a certain pitch, plastic baseballs with indentations showing how to hold the ball to make a certain pitch, and baseball workshops where people could go to learn different pitches. Additional information, including certain difficulties attendant to the problem, was provided in the scenario. The inventor was an individual who develops new baseball instruction materials for a sporting goods company. Thus, the inventor was placed in a role of a PHOSITA. In the scenario, the inventor was asked by his supervisor to develop a new pitching instruction product that allowed the student to actually hold a real baseball while learning how to throw a pitch, but that did not require individual, one-on-one instruction. ${ }^{46}$

To assess the impact of the suggestion test and Graham framework on the hindsight bias without biasing individual responses, a betweensubjects experimental design was used. ${ }^{47}$ Each participant received a single scenario in a single condition. Because the suggestion requirement plays out differently depending on whether there is a suggestion, teaching, or motivation to combine or not, two different base versions of the scenario were used. The first contained no suggestion to combine prior art (this was the same as the original scenario used in the earlier study). A second version of the scenario was modified to add a single explicit suggestion to combine particular prior art, delivered to the inventor by his supervisor. ${ }^{48}$ Following the suggestion to combine would lead to the actual invention at issue.

To test the impact of the Federal Circuit's suggestion instructions on the hindsight bias, foresight, hindsight, and suggestion instruction versions of the scenarios were designed. The foresight (or control) condition included all of the lead-up information and ended with the scenario character trying to solve the identified problem. The hindsight condition was identical to the foresight condition except that it had one additional sentence at its end which stated that the character had come up with a solution, and stated what the solution was. The suggestion instruction condition was identical to the hindsight condition, but the non-obvious

\footnotetext{
46 See Appendix.

47 See David W. Martin, Doing PSychology ExPERIMEnTs 150-53, 172 (6th ed. 2004) (discussing the benefits of a between-subjects experimental design).

48 The suggestion to combine was provided by the following statement from the inventor's supervisor to the inventor as part of the supervisor's instructions: "You know, some inexpensive way to combine an image of how to hold the baseball, like the picture cards, with the ability to actually hold a real baseball." See Appendix.
} 
question in the questionnaire following the scenario included instructions that informed the mock juror of the suggestion, teaching, or motivation requirement, and instructed the mock juror to follow the suggestion requirement in determining whether the invention was non-obvious. ${ }^{49}$

A separate condition was developed to examine the impact of the Supreme Court's Graham framework on the hindsight bias. The Graham instruction condition was identical to the hindsight condition where there was no suggestion to combine in the scenario, except that the questions following the scenario included instructions based on Model Patent Jury Instructions that informed the mock juror of the Graham requirements, and instructed the mock juror to follow these requirements in determining whether the invention was non-obvious. ${ }^{50}$ The study thus included seven different conditions: foresight, hindsight, and suggestion instruction for the scenario with no suggestion to combine references; the same three conditions for the scenario with a suggestion to combine references; and the Graham instruction scenario (see Table 1). Each mock juror received only a single scenario in a single condition.

All participants were asked three substantive questions in the questionnaire portion of the study: (1) whether, in light of the prior art and information provided in the scenario, a solution to the problem was obvious to a person with ordinary skill in the relevant field (participants circled "yes" or "no"), ${ }^{51}(2)$ the confidence the respondent had in their answer to

49 The suggestion instructions used in the scenario stated, "In answering this question, you should first determine whether [the inventor's] invention involved combining parts of the existing instructional materials. If you believe that [the inventor's] invention involved combining parts from existing materials, then you should only conclude that [the inventor's] invention was obvious if you also decide that the existing materials included a suggestion, teaching, or motivation to make the combination." See Appendix. The instructions were modeled to the extent feasible on the FEDERAL CIRCUIT BAR

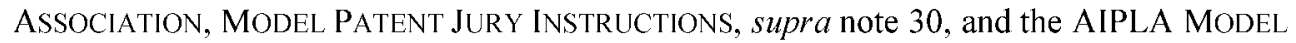
PATENT JURY INSTRUCTIONS, supra note 30. Neither of these standard model patent instructions, however, includes actual suggestion test instructions.

50 The Graham instructions used in the scenario stated, "In answering this question, you should first determine the differences between [the inventor's] invention and the existing instructional materials. You should then decide whether [the inventor's] invention as a whole was obvious in light of all the existing instructional materials." See Appendix. These instructions were based on the FEDERAL Circuit BAR ASSOCIATION, MOdEL PATENT JuRy InSTRUCTIONS, supra note 30, and the AIPLA MODEL PATENT JURY INSTRUCTIONS, supra note 30. Because the scope and content of the prior art was presented in the scenario, this portion of the Graham instruction was excluded. As the scenario was drafted to allow the participant to apply his or her own (lay) understanding of what a PHOSITA would know, the participant was not asked to make separate findings in this regard, but was instructed on this portion of the Graham framework in the non-obvious question. See Part II.A and Appendix.

${ }^{51}$ For instance, the no suggestion scenario, foresight non-obvious question read, "In light of the existing instructional materials and information in the scenario above, do you think a solution to the problem was obvious to a person with ordinary skill in the field of baseball 
the non-obvious query (answered on a scale from $0 \%$ to $100 \%$ with answers indicated in ten percent increments), and (3) the likelihood that the inventor in the scenario would achieve the invention (answered on a scale from 1"not at all likely" to 7-"extremely likely"). Participants were given as much time as desired to consider the patent scenario and answer the questions.

Because the only thing that varied between the foresight and hindsight conditions was the presence of information concerning achievement of the invention (i.e., because all other factors were controlled for), any differences between the foresight and hindsight groups' responses can be attributed to the presence of this information. Similarly, because the only thing that varied between the hindsight and suggestion or Graham instruction conditions was the presence of the particular jury instruction, any differences between the hindsight and instruction groups' responses can be attributed to the presence of the particular instruction at issue..$^{52}$

\section{B. RESULTS}

\section{Non-Obvious}

To corroborate the findings of the earlier study, that hindsight knowledge of an invention increases an individual's judgment of the ex ante obviousness of the invention, Fisher's exact test was run to analyze the frequency of obvious and non-obvious responses in the foresight condition and the hindsight condition. ${ }^{53}$ Separate analyses were conducted for the scenarios that lacked a suggestion to combine and those that included a suggestion to combine.

As expected, participants rated inventions non-obvious significantly more frequently in foresight than in hindsight in both the scenario without a suggestion to combine prior art references $\left(X^{2}=9.462\right.$, Fisher's $\left.p<.01\right)$ and the scenario with a suggestion to combine $\left(X^{2}=15.579\right.$, Fisher's $p<$ $.001)$. Descriptive statistics are presented in Table 1. For the scenario with no suggestion to combine, $42 \%$ of participants (23 out of 55) in the foresight condition thought that a solution to the problem was obvious, while $71 \%$ of participants (39 out of 55) in the hindsight condition thought

instruction at the time [the inventor] was working on the problem?" This question was varied, as appropriate, to include instructions for the instruction conditions. See Appendix. 52 See Andrew J. Wistrich et al., Can Judges Ignore Inadmissible Information? The Difficulty of Deliberately Disregarding, 153 U. PA. L. REV. 1251, 1284 (2005) (stating similar conclusions based on the control versus test groups in their study).

53 As explained in the previous section, throughout this discussion, the term "hindsight condition" refers to the hindsight condition without any instruction. "Suggestion condition" and "Graham condition" are used to refer to the conditions with the particular instructions. Fisher's exact test is a method of statistical analysis for determining whether there is a statistically significant correlation in a dataset containing two variables, each with two possible values. 
that a solution was obvious (see Table 1). Results were similar for the scenario that included the explicit suggestion to combine: $49 \%$ (27 out of 55) of participants in the foresight condition thought that a solution to the problem was obvious, while $85 \%$ (45 out of 53) of those in the hindsight condition thought that a solution was obvious (see Table 1).

Table 1. Participant Responses

\begin{tabular}{|l|c|c|l|c|c|c|}
\hline & $\begin{array}{c}\text { suggestion } \\
\text { in scenario }\end{array}$ & instruction & $\mathrm{n}$ & $\begin{array}{c}\text { obvious } \\
\text { (freq.) }\end{array}$ & $\begin{array}{c}\text { confidence } \\
\text { (mean) }\end{array}$ & $\begin{array}{c}\text { likelihood } \\
\text { (mean) }\end{array}$ \\
\hline foresight & no & none & 55 & $23(42 \%)$ & 68.73 & 4.78 \\
& yes & none & $55^{\mathrm{a}}$ & $27(49 \%)$ & 71.00 & 4.94 \\
\hline hindsight & no & none & 55 & $39(71 \%)$ & 74.55 & 5.38 \\
& yes & none & 53 & $45(85 \%)$ & 74.91 & 5.77 \\
& no & suggestion & $55^{\mathrm{b}}$ & $45(83 \%)$ & 71.45 & 5.56 \\
& yes & suggestion & $56^{\mathrm{a}}$ & $42(75 \%)$ & 71.79 & 5.42 \\
& no & Graham & 55 & $43(78 \%)$ & 74.91 & 5.65 \\
\hline
\end{tabular}

a One participant in each of these conditions did not answer the likelihood question.

b One participant in this condition did not answer the obvious question.

The frequency of participants that judged the invention obvious was higher, in both foresight and hindsight conditions, respectively, for those who received a scenario with a suggestion to combine prior art references than for those who had no suggestion in their scenario. This is not surprising - where the prior art includes an explicit suggestion to combine references the invention should be more obvious than where such suggestion does not exist. This difference, however, was not quite statistically significant $\left(X^{2}=2.442\right.$, Fisher's $\left.p=.077\right)$.

\section{Federal Circuit Suggestion Instructions}

To test the impact of the Federal Circuit's suggestion, teaching, or motivation requirement on non-obvious judgments, Fisher's exact test was run to analyze the frequency of non-obvious responses across the hindsight and suggestion conditions. As above, separate analyses were conducted for the scenarios with and without suggestions to combine prior art references. As expected, suggestion instructions had no significant effect on judgments of obviousness in both the scenario without a suggestion to combine references $\left(X^{2}=2.380\right.$, Fisher's $\left.p=n s\right)$ and the scenario with a suggestion to combine references $\left(X^{2}=1.658\right.$, Fisher's $\left.p=n s\right)$. Regardless of whether there was a suggestion to combine references, mock jurors were no more likely to consider an invention non-obvious when instructed on the Federal Circuit's suggestion, teaching, or motivation requirement than they were in the hindsight condition without instruction. 


\section{Supreme Court Graham Instructions}

To test the impact of the Graham framework instructions on nonobvious judgments, Fisher's exact test was run to analyze the frequency of non-obvious responses across the hindsight and Graham conditions. As expected, Graham instructions had no significant effect on judgments of obviousness $\left(X^{2}=.767\right.$, Fisher's $\left.p=n s\right)$.

\section{Confidence in Non-Obvious Judgment}

Analysis of variance was used to assess the hypothesis that hindsight information is not expected to influence individuals' confidence in their judgment of the obviousness of an invention. Results showed no overall significant effect of hindsight knowledge of invention on participants' confidence in their non-obvious judgments for both the scenario without a suggestion to combine prior art references $\left.\left(F_{(d f}=1,218\right)=2.919, n s\right)$ and the scenario with a suggestion to combine references $\left.\left(F_{(d a f} \quad 1,162\right)=.597, n s\right)$.

Analysis of variance was used to assess whether instructions (either the Federal Circuit's suggestion test or the Supreme Court's Graham framework) influenced individuals' confidence in their judgment of the obviousness of an invention. Results showed no overall significant effect of instruction on participants' confidence in their non-obvious judgments $\left.\left(F_{(d f} 2,271\right)=1.002, n s\right)$. Post-hoc analyses found no significant differences between any of the instruction conditions.

Analysis of variance also was conducted isolating those individuals (in both foresight and hindsight) who judged an invention non-obvious from those who judged an invention obvious. Results showed no overall significant effect of hindsight knowledge of invention for participants who judged an invention non-obvious $\left.\left(F_{(d f} 1,117\right)=3.695, n s\right)$. Results showed an overall significant effect of hindsight knowledge of invention for participants who judged an invention obvious $\left.\left(F_{(d f} 1,262\right)=4.955, p<.05\right)$. For the subset of participants who judged the invention obvious, participants in the hindsight conditions were more confident in their judgments of obviousness $(M=76.4)$ than participants in the foresight conditions $(M=70.2)$.

\section{Likelihood of Invention}

Analysis of variance was used to assess the hypothesis that hindsight knowledge of invention will increase an individual's judgment of the ex ante likelihood of the invention. As expected, there was an overall significant effect of hindsight knowledge of invention on participants' ratings of the ex ante likelihood of invention $\left(F_{(d f=1,380)}=28.059, p<.001\right)$. 
Analysis of variance also was conducted to assess whether instructions (either the Federal Circuit's suggestion test or the Supreme Court's Graham framework) influenced an individual's judgment of the ex ante likelihood of the invention. Results showed no overall significant effect of instruction on participants' judgment of the ex ante likelihood of invention $\left.\left(F_{(d f} \quad 2,270\right)=.418, n s\right)$. Post-hoc analyses found no significant differences between any of the instruction conditions.

\section{Discussion}

The base foresight versus hindsight results, where participants were not instructed on the suggestion test or Graham requirements, confirm the findings of the initial patent study: the hindsight bias significantly prejudices non-obvious decisions. ${ }^{54}$ Participants who were not informed of the invention were substantially more likely to judge a solution non-obvious than participants who were informed what the invention was. This result held across both scenarios-whether there was a suggestion to combine prior art references or not. In addition, individuals making non-obvious judgments in hindsight were equally confident in their (biased) non-obvious judgments as individuals making such (unbiased) judgments in foresight. ${ }^{55}$ Results reported in other studies similarly have found no difference in confidence ratings between participants in foresight and hindsight conditions.56 As discussed in the earlier study, the hindsight impact revealed in this study may actually understate the true non-obvious bias. This occurs because foresight participants evaluate whether any solution is obvious, while hindsight participants are likely focused only on whether the particular invention identified was obvious. ${ }^{57}$ In addition, for inventions with a high level of skill in the art, the increase in PHOSITA skill level over time will exacerbate the hindsight bias. ${ }^{58}$

54 Mandel, supra note 2, at 16 (finding a significant hindsight bias in two different scenarios; one of which (the baseball scenario) was repeated here).

55 This study did find a difference in confidence between foresight and hindsight participants for those judging an invention obvious. See Part II.B.4. The previous patent hindsight bias study found the same difference. Mandel, supra note 2, at 15 . The difference in confidence ratings is relatively small, six points on a one hundred point scale. Its cause is unclear and it appears to be anomalous. No difference in confidence was found in the alternate (fishing lure) invention scenario in the earlier study, either for those judging the invention obvious or non-obvious. Id. Other studies have found no difference in confidence ratings between foresight and hindsight judgment. See, e.g., E. Bukszar \& T. Connolly, Hindsight Bias and Strategic Choice: Some Problems in Learning from Experience, 31 ACAD. MGMT. J. 628, 637 (1988). The difference here indicates that, for participants judging the baseball instruction invention obvious, hindsight participants are more confident than foresight participants, potentially exacerbating the hindsight problem.

56 See, e.g., Bukszar \& Connolly, supra note 56, at 637.

${ }^{57}$ Mandel, supra note 2, at 17.

58 The level of skill in the art of baseball instruction is relatively low. Most inventions will involve a higher PHOSITA skill level, and concomitantly, one that is more likely to 


\section{Non-Obvious: EXPERIMENTAL Study ON THE Hindsight IsSUE}

The focus of the instant study was to assess the effect of the Federal Circuit's suggestion, teaching, or motivation to combine requirement on the hindsight bias. The results indicate that the suggestion requirement does not have a significant effect on mock jurors' conclusions regarding whether an invention is obvious. This result held both for scenarios in which there was an explicit suggestion to combine prior art and for scenarios in which there was no such suggestion. The study indicates that the Supreme Court's Graham framework also does not have a significant effect on the hindsight bias. In addition, individuals receiving the suggestion test or Graham framework instructions did not differ in their confidence ratings from individuals receiving no instruction.

The finding that the suggestion test does not mitigate the hindsight bias comports with a study of every Federal Circuit non-obvious decision over a fifteen-year period, which found that application of the suggestion test did not significantly increase the likelihood of the Circuit to hold an invention non-obvious. ${ }^{59}$ The finding that the suggestion and Graham instructions did not impact the hindsight bias is consistent with the earlier patent study and a study of the hindsight bias in tort law, both of which found no significant effect from juror instructions to avoid the hindsight bias. ${ }^{60}$ The findings also are consistent with a variety of research on jury instruction indicating that the instructions often fail to produce their desired results. ${ }^{61}$

In addition to revealing that the suggestion test does not mitigate the hindsight bias, the absence of a suggestion test effect also indicates that the

increase over time. As the non-obvious determination requires evaluating obviousness from the perspective of a PHOSITA at the time of invention, there will be an added hindsight bias in judging the past, lower level of ordinary skill in the art. To the extent ordinary skill in the art has evolved since the time of invention, the hindsight bias may be exacerbated beyond the findings reported here. $I d$.

59 Lee Petherbridge \& R. Polk Wagner, The Federal Circuit and Patentability: An Empirical Assessment of the Law of Obviousness 43-45, (U. Penn. Institute for Law \& Econ. Research, Working Paper No. http://papers.ssrn.com/sol3/papers.cfm?abstract_id=923309 (reporting that application of the suggestion test did not appreciably affect the rate at which the Federal Circuit affirmed, reversed, or vacated the appealed decision, and a five percent higher non-obvious decision rate in cases in which the Federal Circuit applied the suggestion test when compared with the entire dataset; the authors do not indicate whether this difference is statistically significant).

${ }^{60}$ Mandel, supra note 2, at 15; Kamin \& Rachlinski, supra note 21, at 99.

61 See, e.g., Gregory Mitchell, Why Law and Economics' Perfect Rationality Should Not Be Traded for Behavioral Law and Economics' Equal Incompetence, 91 GEO. L. J. 67, 134 n.209 (2002); Sunstein, supra note 22, at 90-92; John M. Conley, Epilogue: A Legal and Cultural Commentary on the Psychology of Jury Instructions, 6 PSYCHOL., PUB. POL., \& L. 822 (2000) (discussing how the complex effects of jury instructions makes it hard to identify the effects of particular reforms); S.S. Diamond, Instructing on Death: Psychologists, Juries, Judges, 48 AMER. PSYCHOLOGIST 423 (1993); S. Sue et al., Effects of Inadmissible Evidence on the Decisions of Simulated Jurors: A Moral Dilemma, 2 J. APPLIED SOC. PSYCHOL. 345 (1973). 
suggestion requirement does not prejudice a decision-maker towards improperly concluding that an invention is non-obvious. The combination of this study and the prior study reveals that existing patent law does not resolve the hindsight problem.

\section{FROM EXPERIMENTAL STUDY TO REAL WORLD IMPLICATIONS}

Considering the dramatic implications of this study for patent law, it is appropriate to evaluate whether the results are expected to represent the impact of hindsight in actual patent prosecution and litigation. The following discussion analyzes the differences between the present study and real world patent practice, and relies on empirical research to conclude that the study results are anticipated to reflect actual decisions.

This study presented an abstracted version of a non-obvious decision to mock jurors, rather than testing non-obvious decisions in the actual circumstances of patent prosecution and litigation. Here, mock jurors were given a short scenario and relatively brief instructions, and were asked only for individual responses. In practice, non-obvious determinations are made by juries, judges, and Patent and Trademark Office (PTO) examiners. In actual jury patent litigation, for instance, a jury would receive a greater wealth of evidence, plaintiff's and defendant's opposing arguments, more extensive judicial instruction, and be asked to form a group decision. The real world decision-making of judges and PTO examiners differs from the study format as well. Any of these factors theoretically could ameliorate or exacerbate the hindsight bias. These considerations must be evaluated in order to determine how heavily to rely on the study results. These concerns and other potential critiques can be substantially answered based on the results of this study and on a wealth of existing empirical evidence on the hindsight bias and legal judgment.

As a threshold matter, the standard cognitive psychology research methods employed here have proven enormously accurate in representing the actual decision strategies that people engage in when making real world decisions. ${ }^{62}$ Specific research on the hindsight bias similarly indicates that the contextual differences between real world decisions and the mock juror decisions in this study will not alter the results.

One set of potential challenges to this study may be termed "greater seriousness" concerns - assertions that decision-makers in actual settings will apply a heightened level of attention and consideration to the nonobvious determination, and that this greater attention would reduce the hindsight effect. Results from previous hindsight research strongly indicate that this is unlikely. Various hindsight studies have found that increasing

62 See, e.g., Chris Guthrie et al., Inside the Judicial Mind, 86 CORNELL L. REV. 777, 819 (2001); Daniel Kahneman \& Amos Tversky, On the Reality of Cognitive Illusions, 103 PSYCHOL. REV. 582, 582 (1996). 


\section{Non-Obvious: EXPERIMENTAL STUdy ON THE Hindsight IsSuE}

individuals' motivation in performing a task or providing incentives to reach a decision without hindsight impact does not ameliorate the hindsight bias. ${ }^{63}$ Suggesting to people that they try harder, ${ }^{64}$ increasing the personal relevance of the task, ${ }^{65}$ and rewarding people for unbiased responses ${ }^{66}$ all have failed to improve the accuracy of hindsight judgment. Similarly, devoting greater time to a decision does not reduce the bias. ${ }^{67}$

Once an outcome is known, individuals are cognitively incapable of properly discounting it. "[T] he hindsight bias [is] essentially impossible to avoid ... correcting for the bias is not feasible." 68 Real world decisionmakers may well pay more attention to their task than the mock jurors in this study, but paying closer attention to a decision or treating it more seriously does not reduce the hindsight effect. ${ }^{69}$

A second category of possible critique of the present results relates to greater information and detail. Decision-makers in real world patent cases will have substantially more information available to them concerning the invention and the prior art. Empirical studies indicate that this difference does not prejudice the current study. Providing greater information to decision-makers does not ameliorate the hindsight bias. ${ }^{70}$

63 See Guthrie et al., supra note 63, at 819-20 (discussing several studies).

${ }^{64}$ Kamin \& Rachlinski, supra note 21, at 92; M.F. Davies, Reduction in the Hindsight Bias by Restoration of Foresight Perspective: Effectiveness of Foresight Encoding and Hindsight-Retrieval Strategies, 2 Organizational Behav. \& Hum. Decision Making 205 (1987).

65 T. Connolly \& E.W. Bukszar, Hindsight Bias: Self Flattery or Cognitive Error, $40 \mathrm{~J}$. BEHAV. DECISION MAKING 50 (1990).

${ }^{66}$ Kamin \& Rachlinski, supra note 21, at 92; W. Hell et al., Hindsight Bias: An Interaction of Automatic and Motivational Factors?, 16 MEMORY \& COGNITION 533 (1988).

${ }^{67}$ Guthrie et al., supra note 63, at 820.

68 Id. at 824-25.

69 Any argument that the hindsight bias would be ameliorated by the anticipated greater attention, seriousness, and time that decision-makers may apply in actual patent settings would require some basis for patent hindsight exceptionalism - a reason that the hindsight bias in patent law is expected to be more easily debiased than in the myriad other areas where it has proven insoluble in similar circumstances. No such reason is apparent or has been suggested. In addition, the low maximum error rate of one percent on the eligibility questions indicates that participants paid careful attention the questions and responses in the present study. See note 41 and accompanying text.

70 Jeffrey J. Rachlinski, A Positive Psychological Theory of Judging in Hindsight, $65 \mathrm{U}$. CHI. L. REV. 571, 576 (1998); see also Guthrie et al., supra note 63, at 819-21 (discussing a variety of reasons that experimental hindsight bias studies are expected to extrapolate to courtroom decisions). One study in a hypothetical commercial tort litigation context did find that defense counsel arguments could help ameliorate, but not eliminate, the hindsight bias. Merrie Jo Stallard \& Debra L. Worthington, Reducing the Hindsight Bias Utilizing Attorney Closing Arguments, 22 LAW \& HUM. BEHAV. 671, 679 (1998). The debiasing effort here came from the closing argument of the defense attorney, who sought to minimize the effect of the bias by instructing jurors to focus on the pre-outcome time frame and particularly, (1) telling the mock-jurors that the plaintiff's strategy was to have the jurors be "Monday morning quarterbacks," and (2) that the jurors should avoid using 
Similarly, providing more detail does not reduce the bias. ${ }^{71}$ Ironically, increased information and detail may have exactly the opposite effect anticipated by critics raising these challenges-some research has found that increased information and detail actually exacerbates the hindsight problem. ${ }^{72}$ Providing more information to decision-makers in the form of evidence, argument, and instruction is not expected to mitigate the hindsight bias.

A third set of concerns about the instant study relate to the decisionmaker's level of expertise. The mock jurors who participated in this study were, like actual jurors, primarily lay individuals. ${ }^{73}$ The hindsight bias found in this study may be an accurate representation for the over seventy percent of patent trials held before juries ${ }^{74}$ (obviously a significant problem). But, perhaps non-obvious decisions made by judges and PTO examiners are less biased because these decision-makers have expertise in the technology or in making the non-obvious decision, and therefore will not be as impacted as the mock jurors in the study.

As discussed in the earlier patent hindsight article, judges are expected to be equally prone to hindsight bias as jurors. ${ }^{75}$ First, a study of every patent validity decision issued over an eight-year period found no statistically significant difference between the rate at which judges and juries held patents invalid for obviousness, ${ }^{76}$ a result indicating that judges suffer the same hindsight bias as jurors. ${ }^{77}$ Second, a study of 167 federal magistrate judges found that judicial judgments exhibited "hindsight bias to the same extent as mock jurors and other laypersons." 78 Other studies also have found that judges exhibit a hindsight bias similar to laypersons. ${ }^{79}$

hindsight in judging the defendants. $I d$. at 675 . Though intriguing, this finding has not been duplicated in a variety of similar circumstances. Mandel, supra note 2, at 43.

${ }^{71}$ See Guthrie et al., supra note 63, at 820 .

72 See Rachlinski, supra note 71, at 576; Guthrie et al., supra note 63, at 820.

73 Manotti L. Jenkins, A Request to the High Court: Don't Let the Patent Laws Be Distracted by a Flashy Trade Dress, J. MARSHALl J. COMPUTER \& INFO. LAW 323, 358 (1997). Less than twenty percent of the mock jurors in the present study had a postgraduate degree.

74 Adam B. Jaffe \& Josh Lerner, InNOVATION AND ITS Discontents: HOW OUR BROKEN PATENT SYSTEM IS ENDANGERING INNOVATION AND PROGRESS, AND WHAT TO DO ABOUT IT 123 (2004).

75 See Mandel, supra note 2, at 19-21.

${ }^{76}$ Allison \& Lemley, supra note 16, at 214-15.

${ }^{77}$ Mandel, supra note 2, at 19-20.

78 Guthrie et al., supra note 63 , at 803,818 .

79 Id. at 778, 803, 818; John C. Anderson et al., Evaluation of Auditor Decisions: Hindsight Bias Effects and the Expectation Gap, 14 J. ECON. PsYCHOL. 711, 725-30 (1993). A separate pair of related studies found that judges were somewhat less susceptible to the hindsight bias than others. Reid Hastie \& W. Kip Viscusi, What Juries Can't Do Well: The Jury's Performance as a Risk Manager, 40 ARIZ. L. REV. 901, 906 (1998); W. Kip Viscusi, How Do Judges Think About Risk, AM. L. \& ECON. Rev. 26, 29 (1999). These results, however, have been criticized for being biased because "the sample of judges used (those 


\section{Non-Obvious: EXPERIMENTAL STUdy ON THE Hindsight IsSuE}

Third, although familiarity with a task has been identified as providing a slight improvement in the hindsight effect, ${ }^{80}$ judges cannot be considered to be familiar with the technology at issue or even with making non-obvious decisions. Most judges lack any technological training. ${ }^{81}$ The average district judge receives only a few patent cases per year and hears only one patent trial every seven years. ${ }^{82}$ Many of these cases will not contain a nonobvious issue. ${ }^{83}$ In sum, judicial experience and expertise is not anticipated to ameliorate the hindsight effect. ${ }^{84}$

PTO examiners may fare better with the non-obvious hindsight bias. A meta-analysis of over one hundred hindsight bias studies found that individuals familiar with a task, either because they have experienced it or because they have expertise in an area relevant to the task, demonstrate slightly less of a hindsight bias than individuals who are unfamiliar with the task. ${ }^{85}$ PTO examiners are experts in their fields - many hold Ph.D.s in relevant areas and they keep abreast of scientific developments in their areas. ${ }^{86}$ The average PTO examiner evaluates over one hundred patent applications each year, ${ }^{87}$ most of which will have to be evaluated to

who chose to attend a conference on law and economics) and the context within which the study took place (a law and economics conference) may have influenced somewhat more calculated reasoning processes that dampened the [hindsight] effect." Guthrie et al., supra note 63 , at 818 .

80 Christensen-Szalanski \& Willham, supra note 21, at 155. See infra notes 89-93 and accompanying text.

81 Kimberly A. Moore, Markman Eight Years Later: Is Claim Construction More Predictable?, 9 LEWIS \& CLARK L. REV. 231, 246 (2005).

82 Specialized Patent Trial Court, Judges, Debated at House Hearing on Patent Reform, BNA's PATENT, TRADEMARK, \& COPYRIGHT, Oct. 14, 2005, at 657 [hereinafter House Hearing] (citing the testimony of Kimberly A. Moore and John B. Pegram before the House Subcommittee on Courts, the Internet, and Intellectual Property).

83 About one-half of reported patent validity decisions include a non-obvious issue. Allison \& Lemley, supra note 16, at 246. Many patent trials do not involve validity issues, but only infringement, damages, or other claims.

84 Whether judges are better able to decide patent cases than jurors has been questioned in contexts besides the non-obvious standard. Kimberly A. Moore, Are District Court Judges Equipped to Resolve Patent Cases?, 12 FED. CIR. B.J. 1 (2002) (presenting an empirical study that found that district court judges erred in patent claim construction in $33 \%$ of such cases, and concluding that this error rate "creates doubt about the abilities of district court judges to adjudicate complex technical patent cases"); Markman v. Westview Instruments, Inc., 52 F.3d 967, 993 (Fed. Cir. 1995) (Mayer, C.J. concurring) ("There is simply no reason to believe that judges are any more qualified than juries to resolve the complex technical issues often present in patent cases."); Howard T. Markey, On Simplifying Patent Trials, 116 F.R.D. 369, 372 (1987) (arguing that there is no empirical evidence substantiating that trial judges will reach more correct judgments than juries in patent cases).

85 Christensen-Szalanski \& Willham, supra note 21, at 155.

86 Rochelle Dreyfuss, Pathological Patenting: The PTO as Cause or Cure (NYU Law \& Econ. Research, Working Paper No. 05-12, 2005), available at http://ssrn.com/abstract $=787765$.

87 Jaffe \& Lerner, supra note 75, at 131. 
determine whether they are non-obvious. PTO examiners, therefore, will generally be familiar with both the technology surrounding an invention and with the non-obvious task.

The benefit of familiarity for the hindsight bias, however, is slight. The effect size on the hindsight bias identified in the meta-analysis for those familiar with the task was only .2 standard deviation units less bias than for those unfamiliar with the task. ${ }^{88}$ The effect of this improvement on a population will vary depending on how the population is distributedwhether it is evenly split on the non-obvious issue or more one-sided in its judgment. ${ }^{89}$ The greatest effect would occur for a population that is evenly split on the issue, in which case a .2 standard deviation unit change would still represent less than ten percent of the population. ${ }^{90}$ For less evenly split populations, the effect would be far less. ${ }^{91}$ The ten percent upper-bound for the familiarity improvement represents less than one-third of the size of the hindsight effect reported in this study. ${ }^{92}$ PTO examiners thus are still expected to be significantly affected by the hindsight bias, although not quite as severely as judges and jurors.

A final set of challenges to extrapolating to real world non-obvious decisions from the results of this study concerns the effect of group decision-making on the hindsight bias. In a jury trial, the jury deliberates regarding a non-obvious verdict, and the bias may operate in a different manner in a group setting than it does in the individual setting tested in this study. ${ }^{93}$ Two lines of research are useful for evaluating this concern: studies of jury deliberation and studies of the hindsight bias in groups. ${ }^{94}$

Jury deliberation studies indicate that on binary questions (such as whether an invention is non-obvious), jury decision-making appears to

88 Christensen-Szalanski \& Willham, supra note 21 , at 155 . This calculation is based on data for conditions in which an event did occur, the condition most appropriate for the nonobvious determination.

89 Christensen- Szalanski \& Willham, supra note 21 , at 156-60.

90 Less than ten percent of a normally distributed population falls within .1 standard deviations of the mean (.1 standard deviation above the mean plus .1 below adding up to the .2 unit effect size).

91 Where the threshold for a non-obvious determination is not at the mean, the percent of the population affected by the "familiarity improvement" would be less than the ten percent maximum, falling to zero for a non-obvious threshold far from the population mean.

92 See Table 1, supra. The hindsight effect sizes reported here are $31 \%$ and $35 \%$, respectively, for the scenarios in which there was no suggestion to combine prior art references and where there was a suggestion to combine. These effect sizes were calculated combining all hindsight conditions for each type of scenario, as the instruction conditions did not display a significantly different hindsight effect.

93 See David Schkade et al., Deliberating About Dollars: The Severity Shift, 100 CoLum. L. REV. 1139 (2000); James H. Davis et al., Effects of Group Size and Procedural Influence on Consensual Judgments of Quantity: The Example of Damage Awards and Mock Civil Juries, 73 J. PERSONALITY \& SOC. PSYCHOL. 703 (1997).

94 Apparently no one has studied the effect of the hindsight bias on a jury as a whole (as opposed to the effect of the bias on individual jurors). 


\section{Non-Obvious: EXPERIMENTAL Study ON THE Hindsight IssuE}

follow a majority rule in aggregating individual positions to reach a verdict. ${ }^{95}$ Statistically, this would mean that jury verdicts would be equally susceptible to the hindsight bias as individual judgment. Studies on the hindsight bias in groups, conducted in a manner that mirrors the relationship between juror and jury, have found the hindsight bias to be statistically identical in individual and group judgment conditions. ${ }^{96}$ The empirical evidence thus indicates that juries are expected to be impacted by the hindsight bias to the same magnitude as the individual mock jurors reported in this study. ${ }^{97}$

In sum, there is substantial empirical evidence that the results of this study reflect the actual hindsight bias that impacts real world patent decisions. The findings reported here, therefore, have significant import for non-obvious jurisprudence and for the current debate over the Federal Circuit's suggestion, teaching, or motivation to combine requirement.

\section{Consequences of The Hindsight Results for the SuPREME COURT IN KSR V. TELEFLEX}

The issue before the Supreme Court in KSR v. Teleflex is whether the Federal Circuit's requirement that there be some suggestion, teaching, or motivation to combine prior art references in the non-obvious analysis is in error. ${ }^{98}$ Teleflex owns the patent at issue, which pertains to gas pedals for cars and trucks. ${ }^{99}$ The relevant patent claim concerns an adjustable pedal assembly, with an electronic throttle control mounted on the assembly, so that the electronic control does not move during adjustment of the pedal. ${ }^{100}$ Adjustable pedal assemblies, which already existed in the art at the time of patent application, allow drivers to adjust the resting position of the pedal relative to the seat so as to accommodate drivers of different

95 See, e.g., SUNSTEIN ET AL., supra note 22, at 43; James H. Davis et al., Effects of Group Size and Procedural Influence on Consensual Judgments of Quantity: The Example of Damage Awards and Mock Civil Juries, 73 J. PERSONALITY \& SOC. PSYCHOL. 703, 704 (1997) ("Both laboratory studies of mock juries and interviews of actual ex-jurors have reported that ... the initial majority tend[s] to determine [the] verdict." (citations omitted)); see also David Schkade et al., Deliberating About Dollars: The Severity Shift, 100 CoLuM. L. REV. 1139, 1153 (2000) (reporting on the same study as Sunstein). Studies of juror decisions on other, non-binary issues (such as the amount of damages) have found that decisions in these areas do not always represent majority rule. Sunstein, supra note 22, at 43-44; Schkade et al., supra note 96, at 1154-56.

96 Bukszar \& Connolly, supra note 56, at 635, 637; D. Stahlberg et al., We Knew It All Along: Hindsight Bias in Groups, 63 Organizational BeHAV. \& Hum. Decision PROCESSES 46, 49, 52 (1995).

97 Although group decision-making does not resolve the hindsight bias, it does appear to ameliorate some cognitive biases. Stahlberg, supra note 97 , at 48,52 .

98 KSR Int'l Co. v. Teleflex, Inc., 2006 WL 3257150 (U.S.), cert. granted, 75 USLW 3262

(U.S. June 26, 2006) (No. 04-1350).

99 Teleflex, Inc. v. KSR Int'1, Co., 119 Fed. Appx. 282, 283 (2005).

${ }^{100} \mathrm{Id}$. at 283-84. 
heights. ${ }^{101}$ Electronic throttle controls, also already existing in the art, allow operation of the vehicle engine through an electronic sensor that senses the position of the pedal, rather than via a mechanical cable attached to the pedal. ${ }^{102}$ The invention thus allows the pedal to be adjusted, but connects the electronic throttle in such a way that it stays with the pedal during adjustment. Because the elements of the invention at issue were known in the art, the non-obvious issue centers on whether it is appropriate to combine the prior art references in the non-obvious analysis. ${ }^{103}$ If the elements could be combined in the analysis, the invention appears obvious; if the elements could not be combined, it appears non-obvious.

The Supreme Court in Graham established specific steps for the non-obvious analysis: (1) determine the scope and content of the prior art, (2) evaluate the differences between the prior art and the claims at issue, and (3) determine the level of ordinary skill in the art.104 "Against this background, the obviousness or the non obviousness of the subject matter is determined."105 The Supreme Court has considered three non-obvious cases since Graham. ${ }^{106}$ None modified the framework provided in Graham, ${ }^{107}$ and none included consideration of the hindsight bias. The Graham framework remains the foundation of the non-obvious analysis today. As discussed, the current study reveals that the framework does not ameliorate the hindsight bias.

In Graham, the Supreme Court also permitted that secondary consideration evidence, such as evidence of commercial success of an invention or that the invention filled a long-felt need, could be offered to try to establish that an invention was not obvious. ${ }^{108}$ The basis for secondary

$101 \mathrm{Id}$. at $283,286$.

102 Id. at $284,286-87$.

${ }^{103} \mathrm{Id}$. at $286-90$.

104 Graham v. John Deere Co., 383 U.S. 1, 17-18 (1966).

$105 \mathrm{Id}$.

106 Anderson's-Black Rock, Inc. v. Pavement Salvage Co., 396 U.S. 57, 61 (1969); Dann v. Johnston, 425 U.S. 219 (1976); Sakraida v. Ag Pro, Inc., 425 U.S. 273, 282 (1976).

107 In Anderson's-Black Rock, the Court held that a combination of existing elements for laying asphalt pavement into a single machine was obvious. 396 U.S. at 62-63. The Court reasoned that "the combination of old elements . . . added nothing to the nature and quality" of the already patented elements and "did not produce a new or different function." Id. at 60,62. In addition, the Court noted that there was no "synergistic result" created by combining the separate elements, apparently identifying synergism as a potential, but not necessary, means of demonstrating that a combination invention is nonobvious. Id. at 61 . The Court in Dann v. Johnson engaged in a relatively straightforward application of the non-obvious standard, without significant analysis of non-obvious doctrine itself. 425 U.S. 219. Finally, in Sakraida, the Supreme Court relied on its decision in Anderson's-Black Rock in holding that a combination of existing elements in a water flush system for removing animal waste in a barn was obvious, noting that the combination did not produce a synergistic result, or a new or different function. 425 U.S. at 282.

108 Graham, 383 U.S. at 36. 
consideration evidence was to "guard against slipping into use of hindsight" by helping a decision-maker realize that an invention which appears obvious actually may only be obvious in hindsight, and may not have been obvious at the time it was made. ${ }^{109}$ The Supreme Court thus recognized that the hindsight bias had to be mitigated in order to achieve accurate nonobvious decisions.

The first patent hindsight bias study revealed that secondary consideration evidence does not cure the hindsight bias. ${ }^{110}$ Secondary consideration evidence cannot be relied on to significantly ameliorate the hindsight problem for two basic reasons: it often is not available, and even when it is available, it is not particularly probative of whether an invention was non-obvious. ${ }^{111}$ The study results indicate that secondary consideration evidence mitigates the non-obvious hindsight bias in at most a couple percent of cases. ${ }^{112}$ This rate is far too low to solve the hindsight problem.

Thus, neither the Graham framework, subsequent Supreme Court cases, nor secondary consideration evidence cures the hindsight bias. The hindsight problem remains unresolved under existing Supreme Court patent jurisprudence.

\section{A. The Federal Circuit's Suggestion Test}

Out of concern that existing doctrine otherwise leaves non-obvious decisions undefended against the hindsight bias, the Federal Circuit requires that there be some "suggestion, teaching, or motivation to combine" in the prior art in order to combine prior art references in the non-obvious analysis. ${ }^{113}$ Combating the hindsight bias is the sole basis for this test: "To

109 Id. The Federal Circuit subsequently held that it is "error to exclude [secondary consideration] evidence from consideration." Stratoflex, Inc. v. Aeroquip, 713 F.2d 1530, 1539 (Fed. Cir. 1983).

110 Mandel, supra note 2, at 24-27.

111 Robert P. Merges, Commercial Success and Patent Standards: Economic Perspectives on Innovation, 76 CAL. L. REv. 805, 859-72 (1988) (noting that "commercial success is a poor indicator of significant technological advance" and also critiquing the long-felt need, copying, and licensing types of secondary consideration evidence as lacking probative value in many instances); Edmund Kitch, Graham v. John Deere Co.: New Standards for Patents, 1966 SuP. CT. REv. 293 (reprinted in 49 J. PAT. OfF. SOC'Y 237, 282-85) (explaining why commercial success often does not establish that an invention is nonobvious); Ecolochem, Inc. v. Southern Cal. Edison Co., 227 F.3d 1361, 1377-80 (Fed. Cir. 2000) (noting that the commercial success must have resulted from the invention to demonstrate non-obviousness); FED. TRADE COMM'N, supra note 14, ch. 4, at 18-19; Mandel, supra note 2, at 26-27 (discussing and summarizing problems with many types of secondary consideration evidence).

112 Mandel, supra note 2, at 25.

113 In re Dembiczak, 175 F.3d 994, 999 (Fed. Cir. 1999); Ruiz v. A.B. Chance Co., 234 F.3d 654, 665 (Fed. Cir. 2000). See also Manual OF PATENT EXamining Procedure $\S$ 2143.01, Suggestion or Motivation to Modify the References ("Obviousness can only be established by combining or modifying the teachings of the prior art to produce the claimed 
prevent hindsight invalidation of patent claims, the law requires some 'teaching, suggestion, or reason' to combine cited references."'114

The challenge to the suggestion test before the Supreme Court in $K S R$ v. Teleflex is relatively straightforward. Petitioners argue that the test improperly lowers the non-obvious standard by causing inventions for which there is no suggestion to combine references in the prior art to be held non-obvious, even though certain of these inventions actually are obvious. ${ }^{115}$ This contention represents the primary argument raised against the suggestion test by its critics. ${ }^{116}$ Simply because combining references is not suggested by a prior suggestion, teaching, or motivation, these

invention where there is some teaching, suggestion, or motivation to do so found either explicitly or implicitly in the references themselves or in the knowledge generally available to one of ordinary skill in the art."). The caselaw does not draw a distinction between a "suggestion" and a "motivation." Some decisions substitute another term for "motivation" in the suggestion, teaching, or motivation requirement, such as "reason" or "incentive," but this difference in terminology does not appear to indicate any substantive distinction. See, e.g., Gambro Lundia AB v. Baxter Healthcare Corp., 110 F.3d 1573, 1579 (Fed. Cir. 1997) ("Record must provide a teaching, suggestion, or reason to substitute" the patentee's improvement for the disclosure in the prior art); In re Geiger, 815 F.2d 686, 688 (Fed. Cir. 1987) (There must be a "teaching, suggestion, or incentive" to combine prior art references.).

As a formal matter, not all non-obvious determinations concern combining references; some non-obvious determinations are based on whether an invention is obvious in light of single prior art. As a practical matter, however, almost all actual non-obvious determinations are based on combining prior art. See Mandel, supra note 2, at 31-32.

114 Alza Corp. v. Mylan Labs., Inc., No. 06-1019, at*7 (Fed. Cir. Sept. 6, 2006); McGinley v. Franklin Sports, Inc., 262 F.3d 1339, 1351 (Fed. Cir. 2001); see In re Dembiczak, 175 F.3d at 999; In re Kahn, 441 F.3d 977, 986 (Fed. Cir. 2006); Ruiz, 234 F.3d at 665; In re Rouffet, 149 F.3d 1350, 1357 (Fed. Cir. 1998); Nat. Steel Car, Ltd. v. Canadian Pac. Ry., Ltd., 357 F.3d 1319, 1337 (Fed. Cir. 2004).

115 Petition for Writ of Certiorari, KSR Int'l Co. v. Teleflex, Inc., No. 04-1350 (U.S. Apr. $6,2005)$.

116 See FED. TRADE COMM'N, supra note 14, ch. 4, at 12-15 (arguing that the suggestion test is sometimes applied too rigidly in a manner that reads the PHOSITA out of the nonobvious requirement, and fails to take into account the judgment, experience, and common sense of a PHOSITA); NAT'L RESEARCH COUNCIL, A PATENT SYSTEM FOR THE 21ST CENTURY 90 (2004) (explaining that scientists and engineers may not publish obvious information); Brief of the United States, supra note 7, at 11-12 (arguing that the suggestion test permits obvious inventions to receive patent grants); IP Professors' Amici Brief, supra note 9 (arguing that it may be obvious to a PHOSITA to combine references even where there is no suggestion to do so documented in the prior art); Rebecca Eisenberg, Obvious to Whom? Evaluating Inventions from the Perspective of PHOSITA, 19 BERK. TECH. L.J. 885, 888, 897 (2004) (arguing that PHOSITAs apply skills, judgment, intuition, and tacit knowledge that "defy explicit articulation"); Arti K. Rai, Allocating Power over FactFinding in the Patent System, 19 BERK. TECH. L.J. 907, 912-17 (2004) (stating that scientists and engineers may not publish obvious information); John $\mathrm{R}$. Thomas, $A$ Review of Recent Decisions of the United States Court of Appeals for the Federal Circuit: Formalism at the Federal Circuit, 52 AM. U. L. REV. 771, 802 (2003) (contending that the suggestion test reduces PHOSITAs to requiring "specific, step-by-step" combinations in the prior art). 


\section{Non-Obvious: EXPERIMENTAL Study ON THE Hindsight IssuE}

arguments reason, does not necessarily mean that it was not obvious to combine the references. ${ }^{117}$ PHOSITAs, for instance, may not bother to record obvious aspects of ordinary skill in their field, or technological advance may move so rapidly that there is not time to record or publish obvious combinations. ${ }^{118}$ For these reasons, obvious combinations may remain unrecorded in the prior art.

This line of argument critiquing the suggestion test glosses over or misses critical doctrine concerning the suggestion requirement. Under Federal Circuit case law, a decision-maker may rely on an implicit suggestion or motivation to combine prior art references-the suggestion or motivation does not need to be recorded or documented. ${ }^{119}$ Federal Circuit precedent provides two implicit bases, the "nature of the problem to be solved" and the "knowledge of persons of ordinary skill in the art," as acceptable bases for identifying a suggestion or motivation to combine prior art in the non-obvious analysis. ${ }^{120}$ A decision-maker can depend on these criteria, therefore, to identify motivations for combination that no PHOSITA has bothered to record or document, either because the combination seems basic, because technological advance is occurring rapidly, or for some other reason. ${ }^{121}$ Similarly, a decision-maker can depend on these criteria where a motivation to combine comes from a recent technological or other change (such as the internet) or from the context surrounding the invention. The Federal Circuit recently confirmed that a suggestion may be implicit: "A suggestion, teaching, or motivation to combine the relevant prior art teachings does not have to be found explicitly in the prior art." 122

Some critics contend that the Circuit and other courts ignore suggestions from the nature of the problem to be solved or the knowledge of

117 Petition for Writ of Certiorari, KSR, 2006 WL 3257150 (No. 04-1350); FED. TRADE COMM'N, supra note 14, ch. 4, at 12-15; NAT'L RESEARCH COUNCIL, supra note 116, at 90; IP Professors' Amici Brief, supra note 9; Eisenberg, supra note 116, at 888; Rai, supra note 116 , at 912-17.

118 IP Professors' Amici Brief, supra note 9, at 11; NAT'L RESEARCH COUNCIL, supra note 117, at 90; FED. TRADE COMM'N, supra note 14, ch. 4, at 14; Eisenberg, supra note 117, at 888 .

119 Dystar Textilfarben GMBH \& Co. v. C.H. Patrick Co., No. 06-1088, at*7 (Fed. Cir. Oct. 3, 2006); Alza Corp. v. Mylan Labs., Inc. No. 06-1019, at*6 (Fed. Cir. Sept. 6, 2006); In re Rouffet, 149 F.3d at 1357; In re Kahn, 441 F.3d at 987; Ruiz v. A.B. Chance Co., 357 F.3d 1270, 1276 (Fed. Cir. 2004).

120 Dystar Textilfarben, No. 06-1088, at *7; In re Rouffet, 149 F.3d at 1357; In re Kahn, 441 F.3d at 987; Ruiz, 357 F.3d at 1276.

121 Christopher A. Cotropia, The "Suggestion Test" as a Rule of Evidence in Patent Law, http://www.chicagoip.com/speakerprofilesandpapers06S.html.

122 In re Kahn, 441 F.3d at 987; see also Dystar Textilfarben No. 06-1088, at*7; Alza Corp., No. 06-1019, at *6; Ruiz, 357 F.3d at 1276 (holding that the suggestion to combine references may be found implicitly in the nature of the problem to be solved). 
a PHOSITA. ${ }^{123}$ In other words, that the suggestion test case law is appropriate, but applied improperly. Analysis of Federal Circuit nonobvious decisions, however, undermines this claim. First, in almost all nonobvious opinions, the Federal Circuit explicitly identifies the nature of the problem and knowledge of a PHOSITA as potential sources for finding a suggestion to combine references. ${ }^{124}$ Second, a study of all reported Federal Circuit non-obvious decisions over a recent three-year period found many cases in which the Circuit actually relied on implicit forms of suggestion or motivation. ${ }^{125}$ Third, in the few cases in which the Circuit appeared to ignore the potential implicit potential evidence in applying suggestion test, the author of the study concluded that the Circuit was simply applying a rule of evidence to exclude unreliable suggestion evidence, such as mere conclusory statements that a given combination was obvious. ${ }^{126}$ To the extent courts sometimes do not pay proper attention to implicit criteria for combining references, the appropriate response is to clarify these criteria, not to eliminate the entire suggestion test. ${ }^{127}$

Other aspects of the suggestion test and the non-obvious analysis should be clarified as well. The suggestion test only requires a suggestion or motivation to make a combination. Nothing in the test precludes finding an invention obvious in light of a single prior art reference; that is, finding that the invention is only a trivial advance over a particular reference. Similarly, nothing in the test necessarily precludes finding an invention

123 See, e.g., FED. TRADE COMM'N, supra note 14, ch. 4, at 12 (quoting Professor John Duffy as stating that the feel of the case law is that the courts only recognize teachings from the prior art); IP Professors' Amici Brief, supra note 9, at 7-9.

124 Cotropia, supra note 122 , at 15.

125 Cotropia, supra note 122, at 27; see, e.g., Princeton Biochem., Inc. v. Beckman Coulter, Inc., 411 F.3d 1332 (Fed. Cir. 2005) (relying on undocumented knowledge of those skilled in the art and the nature of the problem to be solved to combine references in the nonobvious analysis); Ruiz, 357 F.3d 1270 (stating that there is no "rule of law that an express, written motivation to combine" exists to combine references, and identifying a motivation in the nature of the problem to be solved); Syntex (U.S.A.) LLC v. Apotex, Inc., 407 F.3d 1371 (Fed. Cir. 2005) (relying on undocumented general knowledge in the art in the suggestion test analysis); ISCO Int'l, Inc. v. Conductus, Inc., Nos. 04-1007, 04-1008, 123 Fed. Appx. 974 (Fed. Cir. Feb. 3, 2005) (identifying the knowledge of a PHOSITA as the motivation for the combination); In re Battison, 139 Fed. Appx. 281 (Fed. Cir. 2005) (identifying a suggestion to combine in the ordinary knowledge of a PHOSITA); In re Nylen, 97 Fed. Appx. 293 (Fed. Cir. 2004) (identifying a suggestion to combine in the nature of the problem to be solved); Novo Nordisk A/S/ v. Becton Dickenson \& Co., 304 F.3d 1216 (Fed. Cir. 2002) (affirming jury verdict because there was substantial evidence that a motivation to combine was within the ordinary knowledge of a PHOSITA).

126 Cotropia, supra note 122 , at 22,35 . The author of the study identified just four cases over the three-year period in which the Circuit appeared to ignore implicit evidence of a suggestion to combine references. One of those four was KSR v. Teleflex. Id.

127 Such a solution would satisfy some critics of the suggestion test. The Federal Trade Commission, for instance, recommended providing that the suggestion test include undocumented suggestions, such as from the nature of the problem being solved or from the knowledge of a PHOSITA. FED. TRADE COMM'N, supra note 14, ch. 4, at 15. 
obvious in light of a combination of prior art that does not include every element of the invention - it may have been trivial to add the missing element. These points should be clarified. Focus on the suggestion test appears to have led courts away from such considerations; there are very few cases, for instance, that include an analysis of obviousness in light of single prior art. ${ }^{128}$

\section{B. IMPLICATIONS OF THE STUDY FOR THE SUGGESTION REQUIREMENT}

Beyond the case law not supporting critics of the suggestion requirement, those who argue for elimination of the suggestion test now face an additional substantial hurdle: based on the results of the instant study, the suggestion requirement does not cause the harms attributed to it. Critics of the suggestion requirement argue that, as a result of the suggestion test, inventions are improperly held to be non-obvious in situations where there is no explicit suggestion to combine elements in the prior art, even though the combination may have been obvious. For the scenarios in this study for which no suggestion to combine prior art references existed, however, mock jurors who received the Federal Circuit's suggestion, teaching, or motivation instruction were no more likely to conclude that an invention was non-obvious than mock jurors who received no such instruction. The study indicates that the harm hypothesized to be caused by the suggestion test does not materialize.

That being said, the study results are by no means a ringing endorsement of the suggestion requirement. The results indicate that the suggestion test also does not achieve its primary goal-ameliorating the hindsight bias. Mock jurors who received the suggestion instruction were subject to the same hindsight bias as those who received no instruction. This outcome was consistent whether or not there was a suggestion to combine references in the scenario.

At first blush, these results may appear to leave the fate of the suggestion test, and the outcome in KSR v. Teleflex, uncertain-what to do with a doctrine that does not appear to resolve the problem to which it is directed, but also does not cause the harms with which it is challenged? The answer lies in the hindsight bias.

There are two types of potential error in each non-obvious decision: (1) an erroneous conclusion that an actually non-obvious invention is obvious (Type I error), and (2) an erroneous conclusion that an actually obvious invention is non-obvious (Type II error). ${ }^{129}$ The hindsight bias

128 Mandel, supra note 2, at 31-32.

129 A Type I error is a false positive, and a Type II error is a false negative. SHARON WEINBERG \& KENNETH GOLDBERG, STATISTICS FOR THE BEHAVIORAL SCIENCES 284-85 (1990). In the abstract, it is not clear which problem is worse: is it worse to grant a patent on an obvious (and therefore undeserving) invention, subjecting society to unnecessary monopoly costs and potentially retarding further progress because of the exclusionary 
studies teach us that Type I errors are expected to be much more prevalent in non-obvious determinations than Type II errors. On this basis, the suggestion test should be retained. At worst, it appears to do no harm to non-obvious decisions. To the extent there are certain non-obvious decisions that the suggestion test influences, a possibility discussed below, it may help reduce the hindsight bias in these cases. It is much more likely that the suggestion requirement leads to a greater number of correct nonobvious decisions than it is that the suggestion test corrupts non-obvious determinations.

There is, potentially, a class of cases where the suggestion test may be beneficial in a manner that would not have been identified in the present study. The study discussed above concerning the Federal Circuit's actual application of the suggestion test concluded that the Federal Circuit appears to require a more rigorous application of the suggestion requirement in cases involving complex technology than in cases involving simple technology..$^{130}$ Though such a distinction is not part of suggestion test doctrine, the three-year case survey indicates this difference. ${ }^{131}$ The Federal Circuit thus appears to use the suggestion test as a rule of evidence to exclude unreliable evidence of a suggestion to combine. ${ }^{132}$ For complex technologies, the bar is high-the evidence of an undocumented suggestion must be detailed and precise; for simple technologies, a lower level of detail is required. ${ }^{133}$ The Federal Circuit has never indicated that it is following such a rule, and, contrary to the contours of this analysis, the Circuit in fact has stated that the suggestion test should be applied rigorously in cases involving simple technology inventions because the risk of hindsight is strong in these cases. ${ }^{134}$ The cases analyzed in the evidentiary study, however, indicate that the Federal Circuit does apply a more rigorous standard to suggestion test evidence in cases concerning complex technology.

The distinction between application of the suggestion test for simple versus complex technology may be relevant to understanding the results of the present study. The Federal Circuit appears to perceive less of a need for application of the suggestion test to simple technology. For simple technology, almost any evidence of a suggestion to combine references is

rights in the invention; or is it worse to deny a patent on a non-obvious (and otherwise deserving) invention, thereby denying an inventor their deserved monopoly and providing a lower incentive to invent and innovate than is provided in the Patent Act and believed to be optimal?

${ }^{130}$ Cotropia, supra note 122 , at $35,45-47$.

131 Id. at 20-35.

${ }^{132} \mathrm{Id}$.

133 Id. at $35,45-47$.

134 McGinley v. Franklin Sports, Inc., 262 F.3d 1339, 1351 (Fed. Cir. 2001) ("When the art in question is relatively simple, as is the case here, the opportunity to judge by hindsight is particularly tempting. Consequently, the tests of whether to combine references need to be applied rigorously."). 
considered; for complex technology only more detailed (and therefore potentially more reliable) evidence is permitted. This distinction is at least theoretically supportable. For an invention in a simpler technological field, the (lay) decision-maker will have a better understanding of the prior art, the problem the inventor was working on, and the invention itself. Inventions in complex technological fields, on the other hand, will generally be well beyond the understanding of most judges and jurors. ${ }^{135}$ Judges and jurors, therefore, should be better able to judge on their own whether an implicit suggestion to combine existed in simple technological fields than in complex ones. 136 Whether explicit evidence of a suggestion to combine references existed thus may be less relevant in simple technology cases because jurors and judges will be able to judge whether it was obvious to combine references on their own. ${ }^{137}$

The Federal Circuit's apparent elevated concern about improper reliance on combination evidence for complex technology inventions is supported by hindsight concerns as well. Not only does an invention appear more obvious in hindsight, but suggestion evidence itself also will appear to more obviously lead to the invention. Knowledge of a PHOSITA that may not have actually provided a clear motivation to combine references in foresight may instead appear to provide an obvious suggestion to combine in hindsight. This concern is heightened where the technology is complex, and the decision-maker cannot understand it well. The concern to which the suggestion test is directed - improperly concluding that it was obvious to combine prior art references due to the hindsight bias - may in fact be more prevalent for inventions involving complex technology.

The technology in the scenarios used in the present study was simple-instructional materials for throwing a baseball pitch. It is possible, therefore, that no suggestion test effect was detected here because the intuitive distinction between simple and complex technology cases implicit in the Federal Circuit's application of the suggestion requirement is correct. That is, the suggestion test does not mitigate the hindsight bias in simple technology cases. This leaves open the possibility that the suggestion test does ameliorate the hindsight bias in complex technology cases, a question left unresolved by this study.

In addition, the suggestion test can be seen as providing an analytical framework for decision-makers faced with an otherwise relatively

135 See supra notes 74 and 82 and accompanying text.

136 Cotropia, supra note 122, at 64 ("Lessening of the standard for admissibility coincides with those circumstances where . . . the factfinder can better test the reliability of the testimony on their own.").

137 The insight that simple and complex technology inventions may be handled differently is supported by an empirical study of district court non-obvious decisions which found that more complex technology inventions were more likely to be held non-obvious. See Sean M. McEldowney, New Insights on the "Death" of Obviousness: An Empirical Study of District Court Obviousness Opinions, 2006 STAN. TECH. L. REV. 4, 94. 
unguided decision concerning whether an invention is non-obvious. What "non-obvious" means or requires is not defined in the Patent Act or Supreme Court or Federal Circuit precedent. Where a decision-maker "simply feels" that an invention is obvious (in hindsight), the suggestion test requires that a modicum of rigor be applied to the analysis. The decision-maker must identify some suggestion or motivation in the nature of the problem or the skill of a PHOSITA that would lead to combining references. This is a very broad standard; where the suggestion requirement cannot be met, it should raise substantial concern that a gut feeling the invention is obvious is actually just a result of hindsight bias. In this manner, the suggestion test appropriately guides application of the nonobvious requirement and lends greater predictability and accuracy to nonobvious decisions.

\section{ACHIEving ACCurate Non-Obvious DeCisions}

The failure of the Supreme Court and Federal Circuit to solve the hindsight problem for patent law is not surprising. The hindsight bias has proven to be one of the most difficult cognitive barriers to overcome. A wide-variety of debiasing attempts has generally met with little success. ${ }^{138}$ Alerting people to the hindsight bias and its dangers, ${ }^{139}$ instructing people to try to avoid it, 140 and providing greater education about the topic under consideration $^{141}$ all have failed to reduce the bias. Similarly, as discussed, increasing motivation or incentives, ${ }^{142}$ suggesting to people that they try harder, ${ }^{143}$ increasing the personal relevance of the task, ${ }^{144}$ and rewarding people for unbiased responses ${ }^{145}$ all have failed to improve the accuracy of hindsight judgment. Once individuals have hindsight knowledge they are

\footnotetext{
138 Fischoff, supra note 18, at 343; Baruch Fischoff, Hindsight $\neq$ Foresight: The Effect of Outcome Knowledge on Judgment Under Uncertainty, 1 J. OF EXPERIMENTAL PSYCHOL.: Hum. Perception \& Performance 288, 295 (1975); Kamin \& Rachlinski, supra note 21, at 92; Mandel, supra note 2, at 42-44.

139 Kamin \& Rachlinski, supra note 21, at 92-98; G. Wood, The Knew-It-All-Along Effect, 4 J. Experimental PSychol.: Hum. Perception \& Performance 345 (1978); Baruch Fischoff, Perceived Informativeness of Facts, $3 \mathrm{~J}$. EXPERIMENTAL PSYCHOL.: HuM. PERCEPTION \& PERFORMANCE 349 (1977); Mandel, supra note 2, at 16.

140 Kamin \& Rachlinski, supra note 21, at 92; Wood, supra note 140, at 345; Fischoff, supra note 18, at 349; Mandel, supra note 2, at 16.

${ }^{141}$ See, e.g., Baruch Fischoff, Debiasing, in JUdGMENT UNDER UnCERTAINTY: HeURISTICS AND BIASES 422, 430 (Kahneman et al. eds., 1982).

142 Guthrie et al., supra note 63, at 819-20.

143 M.F. Davies, Reduction in the Hindsight Bias by Restoration of Foresight Perspective: Effectiveness of Foresight Encoding and Hindsight-Retrieval Strategies, 2 Organizational BeHAV. \& Hum. DeCision Making 205 (1987).

144 Connolly \& Bukszar, supra note 56.

145 W. Hell et al., Hindsight Bias: An Interaction of Automatic and Motivational Factors?, 16 MEMORY \& COGNITION 533 (1988).
} 


\section{Non-Obvious: EXPERIMENTAL Study ON THE Hindsight IsSUE}

cognitively unable to discount or ignore that knowledge; they no longer can view prior events objectively. 146

The dilemma that the hindsight bias poses for patent law is severe. Section 103 of the Patent Act dictates that the non-obvious determination be based on whether the invention "would have been obvious at the time the invention was made." 147 This statutory mandate can only be satisfied if the non-obvious determination is made without being prejudiced by hindsight. 148 Consistent with the Patent Act's requirement, the Supreme Court has specified that the non-obvious determination must be free of hindsight bias. ${ }^{149}$ Based on the present study, however, under current jurisprudence, the hindsight problem continues to distort patent law and patent decisions.

The sole means identified to date to debias non-obvious decisions is to bifurcate the non-obvious issue. This method has yet to be tried in actual patent prosecution or litigation. A bifurcation proposal for jury trials is discussed at length in my earlier article on this topic. ${ }^{150}$ The following discussion adds a new proposal for a method to bifurcate the non-obvious issue during initial patent examination before the PTO.

Under the jury trial proposal, pre-trial hearings are used to determine the problem the inventor was working on or the problem the invention solved, the scope and content of the analogous prior art, and the admissibility of any expert testimony concerning the level of ordinary skill in the art and what a PHOSITA would know how to do. The jury would not be informed of the invention. Trial would be conducted based on the problem the inventor was working on, the analogous prior art, and the skill and knowledge of a person having ordinary skill in the art. The jury would deliberate concerning whether the advances sought were obvious to a person having ordinary level skill in the art. By preventing jurors from having hindsight knowledge of the invention in the first instance, the jurors would be placed in the appropriate foresight position to judge whether the invention was non-obvious. ${ }^{151}$

Bifurcation also can be applied at the PTO during initial patent examination to determine whether to grant a patent. Bifurcation at the PTO would require two examiners. The first examiner would conduct a

\footnotetext{
146 See D.A. Schkade \& L.M. Kilbourne, Expectation-Outcome Consistency and Hindsight Bias, 49 Organizational Behav. \& Hum. Decision Processes 108 (1991) (Once an outcome is known, "it becomes difficult to accurately reconstruct a previous state of mind.").

14735 U.S.C. $\$ 103(\mathrm{a})$.

148 See Rich, supra note 12, at 37 ("To protect the inventor from hindsight reasoning, the time is specified to be the time when the invention was made.").

149 Graham v. John Deere Co., 383 U.S. 1, 36 (1966).

150 Mandel, supra note 2, at 45-47.

151 There are a number of important details and potential criticisms of this bifurcation proposal. These items are discussed in the earlier article. Id.
} 
traditional patent review, except he or she would not conduct a non-obvious review. The first examiner would also identify the problem that the inventor was working or the problem that the invention solved, and would determine whether any additional information was required in order to identify the level of skill of a PHOSITA and what a PHOSITA would know how to do. The first examiner would then forward the prior art search, any pertinent information on the level of ordinary skill in the art, and his or her identification of the problem at issue to a second examiner. The second examiner would not see the patent application or be informed of the invention, but would conduct the non-obvious analysis based on the problem the inventor was working on, the analogous prior art, and the skill and knowledge of a PHOSITA.

Where the second examiner concludes that a solution to the problem is not obvious to a person having ordinary skill in the art, then the invention at issue is presumed non-obvious. The invention must be non-obvious if no solution is obvious. If the second examiner concludes that a solution is obvious, he or she should identify what the obvious solutions are before being informed of the actual invention. Comparison of the actual invention to the examiner's solutions will indicate whether the invention was obvious. It may be appropriate to treat the examiner's non-obvious conclusion as strong prima facie evidence concerning whether the invention was nonobvious. In certain instances, once informed of the invention, the examiner may feel that it was actually obvious, but that the problem was identified poorly or misunderstood. The initial conclusion, however, should only be overturned where there is a very strong rationale for doing so. By bifurcating the non-obvious issue to recreate an ex ante analysis, the hindsight bias would be substantially removed from the second examiner's non-obvious decision.

Bifurcation at the PTO will be easier in some regards than bifurcation in jury trials. First, PTO examiners, as experts in their areas of technology, will be better able to apply the skill level of a PHOSITA, and will require less additional information or evidence on the topic. Second, because patent examination occurs closer to the time of invention than patent litigation, and often when the application and invention is not yet disclosed, examiners will be less likely to be familiar with the inventions they are judging. In some instances, jurors will be familiar with the inventions at issue because they have been publicly commercialized prior to infringement litigation. ${ }^{152}$

Bifurcation is not a perfect or complete solution, but would produce far more accurate non-obvious decisions than current methods and jurisprudence. In addition, bifurcation would eliminate the need for the

152 On the other hand, examiners keep up to date with technological advances in their fields, and therefore are expected to be more familiar with any inventions that have been disclosed than jurors. 


\section{Non-ObVIOUS: EXPERIMENTAL StUdy ON THE HindSight IsSUE}

suggestion, teaching, or motivation requirement in the first instance. If there is no hindsight bias then there is no need to mitigate its effect. Both critics and supporters of the suggestion test, therefore, should be able to agree on the bifurcation solution.

Though bifurcation is feasible at the PTO and in many jury cases, ${ }^{153}$ it is not feasible in certain circumstances, particularly for patent cases tried to judges. ${ }^{154}$ In situations where the non-obvious issue cannot be bifurcated, the suggestion requirement should be retained-as discussed, it does not harm non-obvious decisions, and may provide some protection against hindsight, particularly for complex technology inventions. The suggestion test is hardly perfect, but it is the best chance identified so far (outside bifurcation) for potentially ameliorating the hindsight bias. To the extent that caselaw or practice has downplayed the potential for a decisionmaker to identify an implicit suggestion to combine, in the nature of the problem to be solved or from the knowledge of a PHOSITA, these options should be clarified. Elimination of the suggestion requirement, however, would privilege a hypothetical, unconfirmed fear over the significant, confirmed problem of the hindsight bias.

The significant number and intensity of critics of the suggestion test ${ }^{155}$ likely stems in part from a perception among many that too many patents are being granted and held valid, and in particular that too many seemingly obvious patents are be granted or upheld. ${ }^{156}$ The contention that

153 Mandel, supra note 2, at 45-47.

154 The hindsight bias disclosed in the current line of research should caution patent owners against opting out of jury trials in patent litigation. Because the judge will necessarily need to be informed of the invention in a bench trial, the patent owner should have a strong countervailing strategic basis for allowing the hindsight bias in where the decision-maker may otherwise be shielded from it.

155 See supra note 117.

156 See, e.g., FED. TRADE COMm'N, supra note 14, ch.4, at 8-19 (criticizing a low standard for application of the non-obvious requirement and citing the testimony of many patent and economic scholars for the same); NAT'L RESEARCH COUNCIL, supra note 117, at 87-95 (criticizing lenient non-obvious standards, particularly for business method and biotechnology patents); Brief of the United States, supra note 7, at 11-14 (criticizing the suggestion requirement for lowering the non-obvious standard); IP Professors' Amici Brief, supra note 9, at 10 (arguing that Federal Circuit case law sets too low a non-obvious standard); Jaffe \& Lerner, supra note 75, at 32-35, 75, 119-23, 145-49 (criticizing the PTO for granting patents on obvious inventions); Carl Shapiro, Patent System Reform: Economic Analysis and Critique, 19 BERK. TECH. L.J. 1017, 1018 (2004) (noting that complaints regarding the PTO "typically allege that the [PTO] issues too many questionable patents" including those that were "obvious at the time the patent application was filed"); Edited and Excerpted Transcript of the Symposium on Ideas into Action: Implementing Reform of the Patent System, 19 BERK. TECH. L.J. 1053, 1056 (2004) (comment by Mark Myers calling for "reinvigorat[ion of] the nonobvious standard" and noting that panelists "believe that there has been some lowering of the bar of that standard"); Robert P. Merges, As Many as Six Impossible Patents Before Breakfast: Property Rights for Business Concepts and Patent System Reform, 14 BERK. TECH. L.J. 577, 598 (1999) (noting that "[t]he easiest way to raise standards [at the PTO], 
the non-obvious standard as applied is too low (or below that set in the Patent Act or Supreme Court precedent) may or may not be correct. The study reported here, however, reveals that even if the non-obvious standard is too low, it is not because of the Federal Circuit's suggestion test. The suggestion requirement simply does not appear to reduce the likelihood of an invention being held obvious. To the extent the suggestion test may reduce the hindsight bias for certain complex technology patents, there is no reason to believe that these are the same inventions as those improperly held non-obvious as a result of a lenient non-obvious standard. Those who argue for elimination of the suggestion requirement in order to raise the non-obvious bar are trying to solve a problem with a solution that is not commensurate. Inventions which benefit in the non-obvious analysis from application of the suggestion test are not the same as those which are held non-obvious as the result of an allegedly lower standard. The suggestion test thus appears to have been made a scapegoat for problems that commentators see with the non-obvious requirement in general. Eliminating the suggestion test, however, would not ameliorate these problems, and may exacerbate the hindsight bias, potentially leaving the non-obvious requirement in an even more distorted state.

conceptually, is to tighten the nonobviousness requirement of section 103," but acknowledging that this would be difficult); Ashley N. Parker, Problem Patents: Is Reexamination Truly a Viable Alternative to Litigation?, 3 N.C. J.L. \& TECH. 303, 305-07 (2002) (arguing that the PTO has recently granted a number of obvious patents); John H. Barton, Non-Obviousness, 43 IDEA 475, 477-78 (2003) (arguing that the non-obvious standard applied by the PTO and courts today is not as strict as that articulated by the Supreme Court in Graham); Thomas, supra note 117 (criticizing the Federal Circuit for lowering the non-obvious standard and discussing problems at the PTO in conducting nonobvious analyses); McEldowney, supra note 138, at 935 (finding that district courts were less likely to hold a patent invalid as obvious during a five-year period in the 1990s than during a five-year period in the 1970s); Glynn S. Lunney, Jr., E-Obviousness, 7 MiCH. TELECOMM. \& TECH. L. REV. 363 (2001) (asserting that the Federal Circuit has undermined the doctrine of obviousness so as to make it less likely for a court to hold a patent invalid as obvious, and blaming the suggestion test as one of the causes); Bronwyn H. Hall \& Dietmar Harhoff, Post-Grant Reviews in the U.S. Patent System-Design Choices and Expected Impact, 19 BERK. TECH. L. J. 989, 992-100 (2004) (critiquing the PTO for issuing low quality patents and relating the problem to the suggestion test). Compare Petherbridge \& Wagner, supra note 60, at 1 (recognizing that "it is by now a cliché that the United States Court of Appeals for the Federal Circuit has weakened the standards for obtaining patents," but finding based on empirical study of Federal Circuit decisions, "that the conventional wisdom may not be well-grounded.); W. Lesser \& Travis Lybbert, Do Patents Come Too Easy?, 44 IDEA 381, 382 (2004) (arguing, based on empirical study, that patentability standards have not declined over time); Ronald B. Cooley, The Status of Obviousness and How to Assert It as a Defense, 76 J. PAT. \& TRADEMARK OFF. SOC'Y 625, 625 (1994) (noting that "many patent attorneys believe that the obviousness defense is dead," but refuting this proposition in his analysis of Federal Circuit decisions). 


\section{CONCLUSION}

The non-obvious requirement set forth in the Patent Act represents Congress' decision regarding the criterion necessary to promote progress in the technological arts. ${ }^{157}$ Accurate implementation of the non-obvious standard is essential to properly achieving the United States' innovation and technology policy. The non-obvious determination must be based on whether the invention was obvious at the time it was made. Knowledge of the invention, however, inevitably alters the non-obvious evaluation from the proper "obvious at the time" to the improper "appears to have been obvious in hindsight." This study confirms that the answer to the latter question is dramatically different from the answer to the former.

The conclusion of this research is that patent jurisprudence may be no better off concerning the hindsight bias currently than it was when the problem was first considered decades ago. Neither the suggestion requirement, jury instruction to avoid the bias, secondary consideration evidence, or the Graham framework provides an effective means of mitigating the hindsight problem. Non-obvious decisions, as currently conducted, are biased. 158

The non-obvious hindsight bias has confounded the judiciary, lawyers, and others engaged in patent law and patenting for over a century and continues to do so today. Doubtless it will remain an enigma going forward. It is far better, however, to implement the partial and potential fixes available and described here than to simply acknowledge the existence of the bias but pretend, contrary to the data, that decision-makers can somehow avoid it in some undefined, unsubstantiated way.

157 See U.S. CONST. art. $1, \S 8$, cl. 8 (granting Congress the patent power in order "to promote progress").

158 As discussed in the earlier article, decisions under several other patent doctrines suffer from hindsight bias as well. These include decisions under the doctrine of equivalents, claim construction, the on-sale bar, and enablement. Mandel, supra note 2, at 37-42. 


\section{APPENDIX}

\section{Hindsight Bias Study Scenarios ANd Questionnaires}

This Appendix contains the scenario used in this study. Material inside of " \{\} " marks represents the material that varied between the scenario conditions in order to vary conditions between foresight/hindsight, no suggestion to combine/suggestion to combine, and no instructions/Federal Circuit suggestion instructions/Supreme Court Graham instructions. The text in italics is used to explain the varied material and was not included in the scenarios. In addition, there were some minor differences in tense in the questionnaire to account for the different contextual settings.

Please read the following story and then answer the questions on the next page as best as you can, based on the information in the story.

\section{Curveball}

Baseball pitchers throw baseballs in different manners so that they will move differently in order to make it more difficult for a batter to hit the ball. In addition to standard fastballs, pitchers also throw curveballs, sliders, change-ups, and a variety of other pitches, each of which moves in a different manner. The trick to throwing these pitches is to hold the ball differently in your hand and to move your wrist differently as you release the ball.

Baseball pitching instruction is a big business. A wide variety of instructional materials exist in order to teach people, particularly teenagers, how to throw different pitches. These materials include instructional videos showing how to hold and release different pitches, articles and books which describe how to hold and release different pitches, cards which show a picture of a hand holding a baseball in the proper way to make a certain pitch, plastic baseballs with indentations showing how to hold the ball to make a certain pitch, and baseball workshops where people can go to learn different pitches.

Mike works in the Baseball Instruction division of PlayBall Inc., a sporting goods company that markets a variety of instructional baseball materials. Mike's job is to develop new baseball instruction materials; his knowledge and skill in developing new baseball instruction materials would be considered ordinary for people working in the field. 
Mike's supervisor has told him that PlayBall would like to develop and market a new pitching instruction product. The supervisor says that the indented plastic baseballs and baseball workshops provide much better instruction than other materials because the student is actually holding the baseball as s/he learns how to throw a pitch. However, both of these options have problems. The plastic baseballs do not give the feel or action of real baseballs, and you need a whole set of them to throw different pitches. The workshops provide the greatest instruction, but are very expensive compared to the other materials. Mike's supervisor asks Mike to try to come up with an inexpensive product that will do a better job of teaching new pitches than the videos, articles and books, cards, and plastic baseballs on the market. \{Suggestion to combine prior art reference scenarios included the following text: "You know, some inexpensive way to combine an image of how to hold the baseball, like the picture cards, with the ability to actually hold a real baseball," Mike's supervisor says.\}

\{Hindsight scenarios included the following text: Mike comes up with the idea of placing ink markings on an actual baseball indicating how to hold the ball for various pitches, creating an inexpensive instructional device that allows the student to actually hold the baseball while learning. $\}$

[please continue to questions on next page]

$\{$ page break\}

Based on the information provided in the story, please answer the following three questions as best you can. Please circle your answers.

1) Do you think Mike's invention was obvious to a person with ordinary skill in the field of baseball instruction at the time Mike was working on the problem, in light of the existing instructional materials and information?

$\{$ Federal Circuit suggestion instruction scenarios included the following text:

- In answering this question, you should first determine whether Mike's invention involved combining parts of the existing instructional materials. If you believe that Mike's invention involved combining parts from existing materials, then you should only conclude that Mike's invention was obvious if you 
also decide that the existing materials included a suggestion, teaching, or motivation to make the combination.\}

\{Supreme Court Graham instruction scenarios included the following text:

- In answering this question, you should first determine the differences between Mike's invention and the existing instructional materials. You should then decide whether Mike's invention as a whole was obvious in light of all the existing instructional materials.

Yes $\quad$ No

2) How confident are you of your answer to Question 1 above?

$\begin{array}{lllllllllll}0 \% & 10 \% & 20 \% & 30 \% & 40 \% & 50 \% & 60 \% & 70 \% & 80 \% & 90 \% & 100 \%\end{array}$ not at all moderately absolutely confident confident confident

3) How likely was it that Mike would figure out a solution to the problem he was working on?

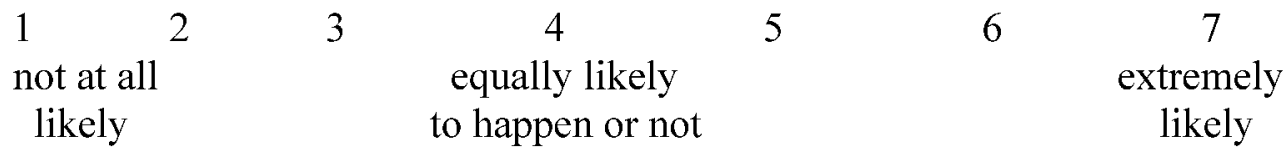
a) What is your gender?
Female
Male
b) Are you a United States citizen?
Yes
No
c) Have you been convicted of a felony?
Yes
No
d) What is your age (in years)?
e) Check-off the highest education you have completed.

No high school

High school graduate

4-year college degree
Some high school

Some college or a 2-year college

Graduate degree

(e.g.,MA/PhD/MD/JD) 
Non-Obvious: EXPERIMENTAL Study ON THE Hindsight IsSuE

f) What is your racial/ethnic background?

$\begin{array}{ll}\begin{array}{c}\text { White/Caucasian } \\ \text { (non-Hispanic) } \\ \text { Hispanic }\end{array} & \begin{array}{c}\text { Black/African-American } \\ \text { (non-Hispanic) }\end{array} \\ \text { Other } & \text { Asian }\end{array}$

[End of study. Thank you for your participation.] 